Cite this: Chem. Soc. Rev., 2011, 40, 3879-3894

\title{
Electrodeposited lead dioxide coatings
}

\author{
Xiaohong Li, ${ }^{* a}$ Derek Pletcher $^{b}$ and Frank C. Walsh ${ }^{a}$ \\ Received 15th December 2010 \\ DOI: $10.1039 / \mathrm{cocs00213e}$
}

Lead dioxide coatings on inert substrates such as titanium and carbon now offer new opportunities for a material known for 150 years. It is now recognised that electrodeposition allows the preparation of stable coatings with different phase structures and a wide range of surface morphologies. In addition, substantial modification to the physical properties and catalytic activities of the coatings are possible through doping and the fabrication of nanostructured deposits or composites. In addition to applications as a cheap anode material in electrochemical technology, lead dioxide coatings provide unique possibilities for probing the dependence of catalytic activity on layer composition and structure (critical review, 256 references).

\section{Introduction}

Electrode coatings are now extensively employed to improve the performance of modern electrochemical technology. ${ }^{1}$ Lead dioxide $\left(\mathrm{PbO}_{2}\right)$ is perhaps the grandfather of such coatings first investigated more than 150 years ago. ${ }^{2}$ The earlier studies and applications were, however, limited to coatings formed in situ on lead or lead alloys and anodes of this type always

${ }^{a}$ Electrochemical Engineering Laboratory,

School of Engineering Sciences, University of Southampton,

Highfield, SouthamptonSO171BJ, UK.E-mail:Xh.Li@soton.ac.uk

${ }^{b}$ School of Chemistry, University of Southampton, Highfield,

Southampton SO17 1BJ, UK suffered from continuous corrosion of the underlying lead substrate. It is only much more recently that the preparation by electrodeposition of stable lead dioxide layers on inert substrates (typically titanium or carbon) has re-ignited interest in lead dioxide as an anode material. The reasons for this interest are clear. Lead dioxide coatings have a low cost compared to those based on precious metals, high electrical conductivity (comparable to metals), high oxygen overpotential and good stability in controlled conditions leading to possible application in new processes. In addition, from an academic viewpoint lead dioxide is a fascinating material. Lead dioxide coatings can be prepared with different phase structures, a wide range of surface morphologies and as both doped and

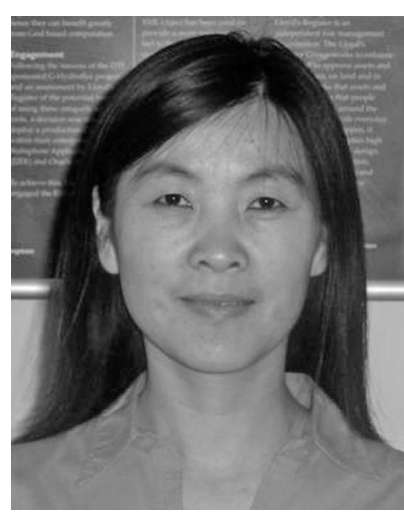

Xiaohong Li
Dr Xiaohong $\mathrm{Li}$ received a $B S c$ in Organic Chemistry (Lanzhou University), a MSc in Analytical Chemistry (Lanzhou University) and a PhD in Physical Chemistry (Lanzhou University \& Peking University). After experience as an engineer/project manager for PetroChina Ltd, since 2003, Xiaohong Li has worked in the University of Southampton and is now a Senior Consulting Engineer in the Research Institute for Industry in the School of Engineering Sciences. Her research interests include flow batteries, water electrolysers, and nanoscale materials (for electrocatalysis, optoelectronics, thermoelectric devices and sensors). Xiaohong $\mathrm{Li}$ is the author of $>40$ papers and is a member of both the International Society of Electrochemistry and the US Electrochemical Society.

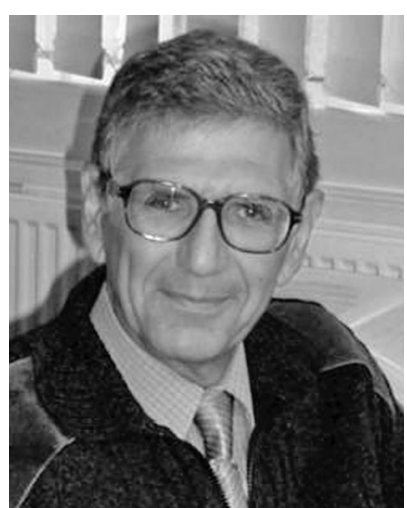

Derek Pletcher
Derek Pletcher obtained his $B S c$ and PhD in Chemistry from the University of Sheffield and has been a member of the Electrochemistry Group in Southampton since 1967 (presently, a Professor Emeritus). His research involving $>200$ co-workers has sought to build bridges between fundamental electrochemistry and electrochemical technology. These activities have resulted in $>330$ papers and $>30$ reviews. Derek Pletcher has been a consultant to companies in Europe and North America, an organiser/ presenter of short courses for academic and industrial audiences and an author including "A First Course in Electrode Processes" (RSC, 2009). He is a Fellow of US Electrochemical Society and has been awarded prizes including the Vittorio de Nora Prize (US Electrochem. Soc., 2010). 
undoped materials giving rise to significantly different catalytic activities. In the long term, lead dioxide can contribute substantially to a fundamental understanding of the relationship between the coating structure and catalytic activity, important to all fields of catalysis.

This review focuses on lead dioxide coatings, typically with a thickness of 5-20 $\mu \mathrm{m}$, formed ex situ by electrodeposition onto inert substrates such as titanium or carbon from aqueous electrolytes containing $\mathrm{Pb}(\mathrm{II})$. Those formed in situ on lead metal or lead alloy anodes in media such as sulfuric acid where an insoluble lead(II) compound is an intermediate in the formation of the lead dioxide layer are only considered where knowledge of their chemistry is helpful to the story of lead dioxide layers on inert substrates. Discussion of the lead dioxide electrode as met in the positive plate in the lead-acid battery will be completely excluded; in this context, the electrode consists of a thick layer of $\mathrm{PbSO}_{4} / \mathrm{PbO}_{2}$ paste, quite different from the anode coatings considered here. Even so, it should be recognised that the lead-acid battery is to be found in all automobiles and is, perhaps, the battery most familiar to the layman - it still represents some $40-45 \%$ of the sales value of all batteries worth some $\$ 15$ billion to their manufacturers. The interested reader is referred to a number of texts that cover lead-acid battery technology. ${ }^{3-10}$

Much of the recent literature addresses the twin goals of developing lead dioxide coatings that allow high current densities and efficiencies for particular electrode reactions and enhanced stability of the coating. Long term stability is always a critical issue when lead dioxide anodes are considered because corrosion of the coating must lead to contamination of the product/effluent with toxic lead(II). This review will highlight the extensive literature of the past twenty years and cover the chemistry and electrochemistry of lead dioxide layers formed by electrodeposition, the influence of deposition conditions on the structure and properties of the $\mathrm{PbO}_{2}$ layers including doped, composites and nanostructured layers.

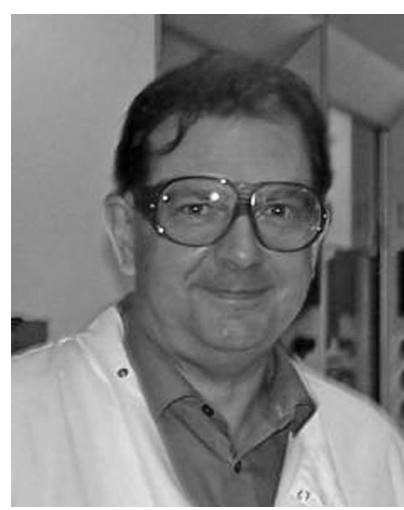

Frank C. Walsh
Frank Walsh received a BSc in Applied Chemistry (University of Portsmouth), a MSc in Materials Protection (UMIST) and a PhD in Electrochemical Engineering (University of Loughborough). Following periods in industry and academic appointments in Portsmouth, Strathclyde and Bath, he is now a Professor in the School of Engineering Sciences at the University of Southampton, leading the Electrochemical Engineering Group. Frank Walsh is the author of $>300$ papers and 4 books, a willing participant in short courses and an active consultant. He has been an Invited Lecturer at International Conferences throughout the world and received a number of awards, most recently election as a Fellow of NACE International (the International Society focused on corrosion).
It will also consider potential applications of such $\mathrm{PbO}_{2}$ anodes. We are not aware of any substantial reviews of lead dioxide electrodes in recent years. The history and fundamental chemistry of $\mathrm{PbO}_{2}$ anodes is covered in 1972 and 1986 reviews by Hampson, ${ }^{5,11}$ a 1979 book by Kuhn, ${ }^{8}$ a 1990 Chemical Review of electrode materials ${ }^{12}$ and a more recent chapter by Salkind et al. ${ }^{10}$ The period since the last review has seen major developments in lead dioxide coatings.

\section{Basic electrochemistry}

\subsection{Thermodynamics}

Lead dioxide may be electrodeposited onto inert substrates such as titanium or carbon from a number of media where the $\mathrm{Pb}(\mathrm{II})$ is soluble, e.g. nitric acid, perchloric acid, methanesulfonic acid, acetate buffer when the $\mathrm{Pb}$ (II) is present as $\mathrm{Pb}^{2+}$ or sodium/potassium hydroxide when the $\mathrm{Pb}(\mathrm{II})$ is present as plumbite. In the acidic media the overall electrode reaction may be written

$$
\mathrm{Pb}^{2+}+2 \mathrm{H}_{2} \mathrm{O} \rightarrow \mathrm{PbO}_{2}+4 \mathrm{H}^{+}+2 \mathrm{e}^{-}
$$

and in the alkaline media

$$
\mathrm{HPbO}_{2}^{-}+\mathrm{OH}^{-} \rightarrow \mathrm{PbO}_{2}+\mathrm{H}_{2} \mathrm{O}+2 \mathrm{e}^{-}
$$

At $298 \mathrm{~K}$, the equilibrium potential for the $\mathrm{PbO}_{2} / \mathrm{Pb}$ (II) couple is given by ${ }^{13}$

$$
E_{\mathrm{e}}(1)=1.455-0.029 \log a_{\mathrm{Pb}^{2+}}-0.118 \mathrm{pH}
$$

Fig. 1 shows the equilibrium potential plotted as a function of $\mathrm{pH}$ for two concentrations of $\mathrm{Pb}$ (II) and the equilibrium potential for the $\mathrm{O}_{2} / \mathrm{H}_{2} \mathrm{O}$ reaction as a function of $\mathrm{pH}$. Three conclusions are evident:

(i) In acid solution and on open circuit, lead dioxide is only metastable since its dissolution by reaction with water to give oxygen and $\mathrm{Pb}$ (II) is always thermodynamically favourable. In media where the only $\mathrm{Pb}$ (II) in solution arises from corrosion of the $\mathrm{PbO}_{2}$ coating (as, for example, in any application of a $\mathrm{PbO}_{2}$ anode), lead dioxide will be metastable even in neutral solutions.

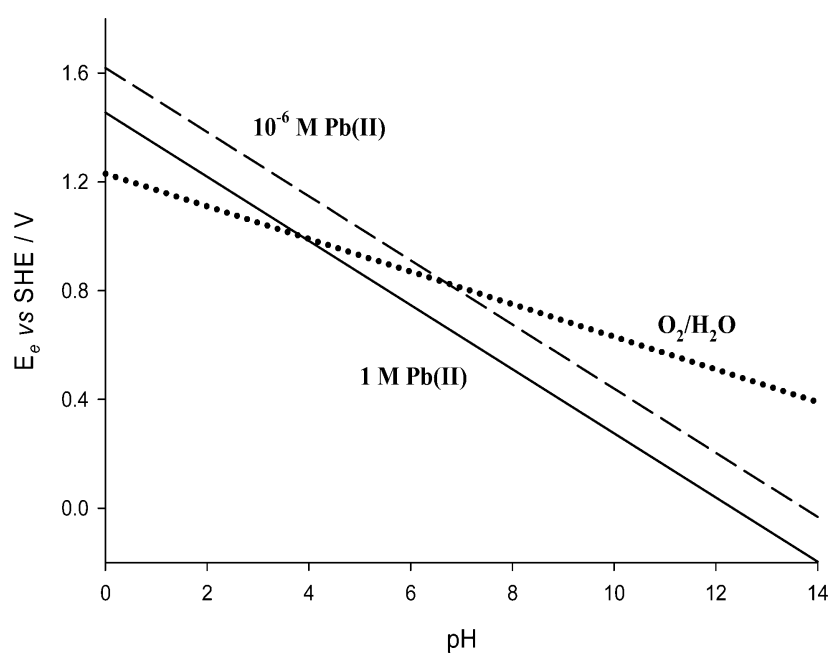

Fig. 1 The equilibrium potential for the $\mathrm{Pb}(\mathrm{IV}) / \mathrm{Pb}$ (II) plotted as a function of $\mathrm{pH}$ for two concentrations of $\mathrm{Pb}$ (II) and the equilibrium potential for the $\mathrm{O}_{2} / \mathrm{H}_{2} \mathrm{O}$ reaction as a function of $\mathrm{pH}$. 
Only in alkaline solutions will lead dioxide be thermodynamically stable. When employed in a practical electrolysis when the electrolyte may contain organics, halides or other species, the rate of corrosion will also need to consider oxidation of these species by lead dioxide (lead dioxide is, in fact, used as an oxidant in organic synthesis). All such oxidisable species will accelerate corrosion.

(ii) Lead dioxide electrodes can only be used in applications that require a rather positive potential. If a potential positive to the equilibrium potential is applied, the coating will be protected from corrosion. On the other hand, at any potential significantly negative to the equilibrium potential, cathodic reduction and dissolution of the lead dioxide coating are to be expected.

(iii) The substrate material must be stable to corrosion at the high positive potentials used both for the electrodeposition of the $\mathrm{PbO}_{2}$ layer and the applications of the coated electrodes; pinholes and other faults in the coating are always possible and will lead to exposure of the substrate to the electrolyte with a consequent risk of substrate corrosion.

When a lead dioxide coating is formed in situ on a lead surface in sulfuric acid media, the anode reactions are:

$$
\begin{aligned}
\mathrm{Pb}+\mathrm{SO}_{4}{ }^{2-} & \rightarrow \mathrm{PbSO}_{4}+2 \mathrm{e}^{-} \\
\mathrm{PbSO}_{4}+2 \mathrm{H}_{2} \mathrm{O} & \rightarrow \mathrm{PbO}_{2}+4 \mathrm{H}^{+}+\mathrm{SO}_{4}{ }^{2-}+2 \mathrm{e}^{-}
\end{aligned}
$$

and the equilibrium potentials are given by ${ }^{13}$

$$
\begin{aligned}
& E_{\mathrm{e}}(4)=-0.356-0.029 \log a_{\mathrm{SO}_{4}^{2-}} \\
& E_{\mathrm{e}}(5)=1.685+0.029 \log a_{\mathrm{SO}_{4}^{2-}}-0.118 \mathrm{pH}
\end{aligned}
$$

Again it may be concluded that this layer is metastable on open-circuit in acid media because of reaction with water to give oxygen and except at very positive potentials that the layer will undergo cathodic reduction. In addition, however, it is clear that if any lead substrate is exposed to the sulfuric acid medium, there is a strong driving force for corrosion and perhaps the formation of a less conductive film via reaction (4).

Studies of $\alpha-\mathrm{PbO}_{2}$ and $\beta-\mathrm{PbO}_{2}$ would indicate that the phase has little influence on the thermodynamics of the reactions above, the equilibrium potentials differing by approximately $10 \mathrm{mV} .^{10}$ The $\beta-\mathrm{PbO}_{2}$ phase is, however, thermodynamically the more stable phase. ${ }^{5,10}$

\subsection{Kinetics}

Fig. 2 shows typical cyclic voltammetry for the deposition and dissolution of lead dioxide onto an inert substrate. ${ }^{14}$ The voltammograms were in fact recorded for a vitreous carbon disc electrode in a methanesulfonic acid solution and the $1^{\text {st }}$ and $5^{\text {th }}$ scans are shown but the voltammetry would be similar for other inert substrates and acid media. On the first scan with a clean vitreous carbon surface, deposition does not commence until close to the positive limit and the anodic current density is higher at the beginning of the reverse sweep. On the $5^{\text {th }}$ scan, the deposition current density commences at substantially lower potential, say $+1.63 \mathrm{~V}$ and the current densities are much larger and tending to a mass transport controlled plateau beyond $+1.70 \mathrm{~V}$. Reduction of the $\mathrm{PbO}_{2}$ layer back to $\mathrm{Pb}^{2+}$ is seen as a sharp symmetrical cathodic

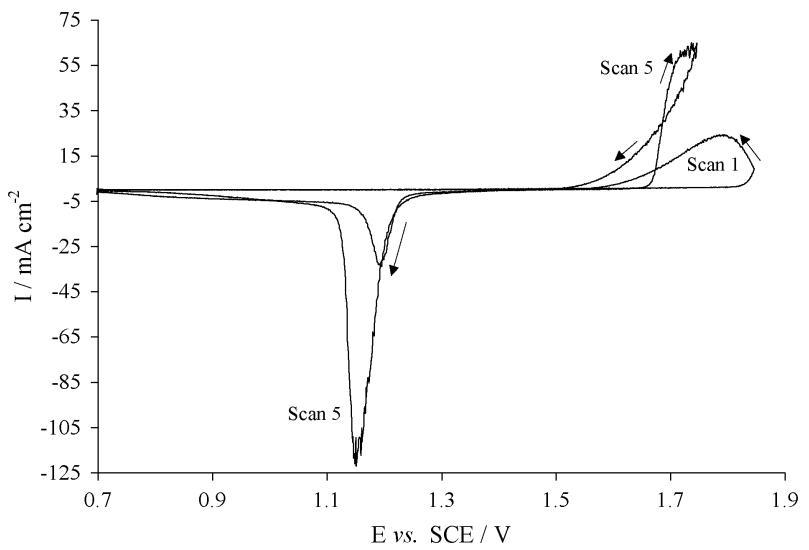

Fig. 2 Cyclic voltammograms recorded at a rotating vitreous carbon disc electrode $(\omega=200 \mathrm{rpm})$ in a solution of lead(II) $(300 \mathrm{mM})$ in aqueous methanesulfonic acid ( $2 \mathrm{M}$ ). The figure shows the first scan after polishing the vitreous carbon disc and the fifth during continuous cycling. Potential scan rate $50 \mathrm{mV} \mathrm{s}^{-1}$. Temperature $298 \mathrm{~K} .{ }^{14}$ Reproduced by permission of The Royal Society of Chemistry.

peak commencing about $+1.20 \mathrm{~V}$. With potential cycling, this peak grows as a thicker $\mathrm{PbO}_{2}$ layer is deposited. All these features are typical of a deposition reaction involving nucleation and growth of a phase on an electrode. Furthermore, the limiting current density towards the positive limit on the $5^{\text {th }}$ cycle confirms that $\mathrm{PbO}_{2}$ may be electrodeposited at a high rate. There is charge balance between deposition and dissolution of the lead dioxide but even when a $\mathrm{PbO}_{2}$ layer is present, the $\mathrm{PbO}_{2} / \mathrm{Pb}^{2+}$ couple is not electrochemically reversible - there is a potential range between $+1.50 \mathrm{~V}$ and $+1.20 \mathrm{~V}$ when almost no current is observed. But the clear conclusion is that a $\mathrm{PbO}_{2}$ coating will not be stable negative to $+1.20 \mathrm{~V}$.

Voltammograms for the deposition and dissolution of $\mathrm{PbO}_{2}$ at most inert substrates and in many media are very similar to that shown in Fig. 2 and hence these conclusions are general for all media. Indeed the voltammetry of lead in sulfuric acid shows similarity as the formation of lead sulfate passivates the surface until conversion to lead dioxide occurs and reduction of lead dioxide back to lead sulfate gives a similar cathodic peak. ${ }^{5,15}$ It is interesting to note, however, that the kinetics of the $\mathrm{PbO}_{2} / \mathrm{PbSO}_{4}$ couple are significantly faster than the $\mathrm{PbO}_{2} / \mathrm{Pb}^{2+}$ couple leading to lower overpotentials for both formation and reduction of $\mathrm{PbO}_{2}$.

The mechanisms for the formation and reduction of $\mathrm{PbO}_{2}$ are multistep and complex and remain the topic of study and speculation (see later). They will also depend on the system and conditions. Hence, it is not helpful to discuss quantitative kinetics. The voltammetry in Fig. 2, however, is a useful guide to the behaviour of lead dioxide layers in practice.

\subsection{Phase composition and structure}

Lead dioxide is polymorphic and the two modifications are well defined. $\alpha-\mathrm{PbO}_{2}$ has the orthorhombic structure of columbite (space group $\mathrm{Pbcn}, V_{\mathrm{h}}{ }^{14}$ ) and $\beta-\mathrm{PbO}_{2}$ has the tetragonal, rutile structure (space group $P 4 / m n m, D_{4 h}{ }^{14}$ ). ${ }^{5,16}$ In both cases (Fig. 3), each lead(IV) ion is in the center of a distorted octahedron and the essential difference is in the way in which the octahedra are packed. In $\beta-\mathrm{PbO}_{2}$, neighbouring 
$\alpha-\mathrm{PbO}_{2}$

(Orthorhombic)
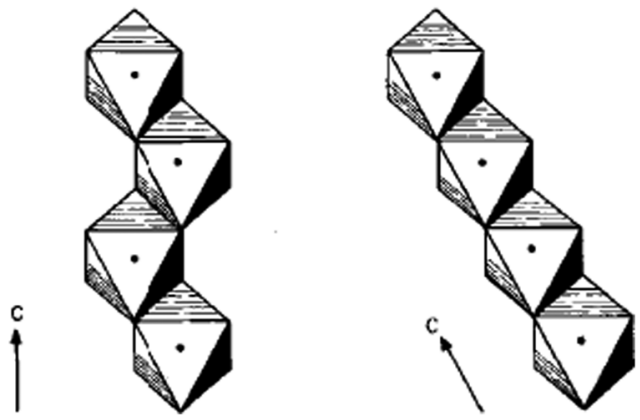

Fig. 3 The structures of $\alpha-\mathrm{PbO}_{2}$ and $\beta-\mathrm{PbO}_{2} \cdot{ }^{16}$ The structures are based on the same oxygen octahedra but the octahedra are packed in a different way. Reproduced by permission of The Electrochemical Society.

octahedra share opposite edges, which results in the formation of linear chains of octahedra. Each chain is connected with the next one by sharing corners. In $\alpha-\mathrm{PbO}_{2}$, neighbouring octahedra share non-opposite edges in such a way that zig-zag chains are formed. Each chain is connected with the next one also by sharing corners.

$\alpha-\mathrm{PbO}_{2}$ and $\beta-\mathrm{PbO}_{2}$ can be readily and qualitatively distinguished from each other using $X$-ray diffraction. Fig. 4 shows the standard powder diffraction patterns for the two phases. ${ }^{17}$ Strong diffraction peaks of both phases are present in the $2 \theta$ range $20^{\circ}-40^{\circ}$ and the peaks are clearly distinguishable. There can, however, be problems with the quantitative determination of the ratio of $\alpha-\mathrm{PbO}_{2} / \beta-\mathrm{PbO}_{2}$ phases due to a number of factors. ${ }^{5,18-22}$ Even so, Dodson ${ }^{23}$ and Munichandraiah ${ }^{24}$ proposed a method for estimating the relative amounts of $\alpha-\mathrm{PbO}_{2}$ and $\beta-\mathrm{PbO}_{2}$ in mixtures of the two phases, which gave reproducible results within an error of $5 \%$.

Moseley et al. ${ }^{25}$ used high resolution transmission electron microscopy to investigate the real space structure of crystals of $\mathrm{PbO}_{2}$ and explained the difficulties in refining the crystal structure of $\mathrm{PbO}_{2}$ with the X-ray powder diffraction technique.

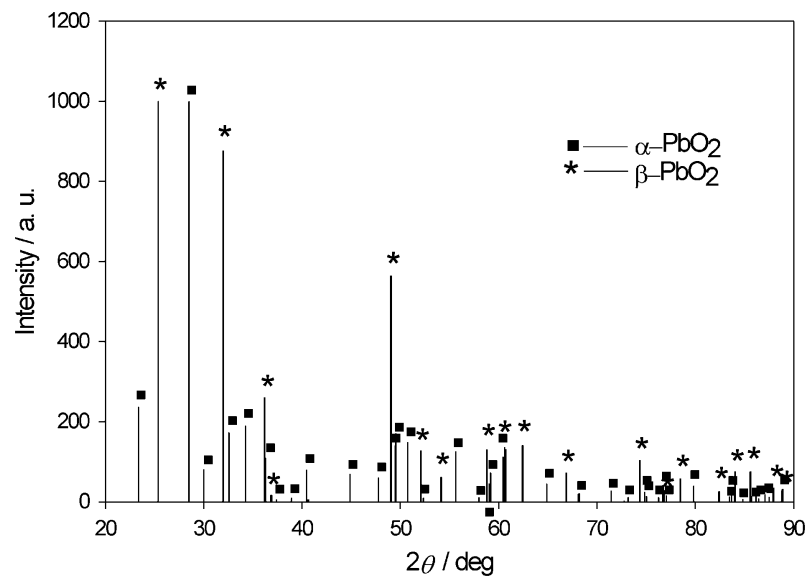

Fig. 4 Standard powder diffraction patterns recorded for samples of pure $\alpha$ - and $\beta$-phases of $\mathrm{PbO}_{2}$.
A variety of crystal defects that had passed undetected by conventional powder diffraction were revealed. $\alpha-\mathrm{PbO}_{2}$ with an apparently clean X-ray powder diffraction pattern was observed largely composed of crystals typified by extensive structural faulting. This faulting was manifest in an X-ray study only by a failure to achieve a satisfactory structural refinement. By contrast, a refinement of the $\beta-\mathrm{PbO}_{2}$ structure converged well and the extent of crystal faulting appeared to have been much less. The recognition of this structural degree of freedom in $\mathrm{PbO}_{2}$ is significant in view of its potential influence on properties such as electronic conductivity and electrochemical activity.

It is important to recognize that neither of the two modifications is fully stoichiometric and this is the reason for its high conductivity. The chemical compositions is correctly represented by $\mathrm{PbO}_{2}-\delta \cdot\left(x \mathrm{H}_{2} \mathrm{O}\right)$. The index " $2-\delta$ " indicates that there exists a variable deviation from the ideal stoichiometry, and the " $x \mathrm{H}_{2} \mathrm{O}$ " states that a variable amount of water is dispersed through the $\mathrm{PbO}_{2} \cdot{ }^{6,26}$ Although this formula is convenient from the purely analytical point of view, it is somewhat misleading with regard to the crystallographic interpretation of non-stoichiometry. In fact, the anionic sublattice of the structure is known to be complete, and the dense packing of $\mathrm{O}^{2-}$ ions excludes the presence of "interstitial" $\mathrm{H}_{2} \mathrm{O}$ or $\mathrm{OH}^{-}$. The deviation from stoichiometry is caused by structural disorder in the cationic sublattice. Rüetschi ${ }^{27}$ proposed a detailed model where $\mathrm{PbO}_{2}$ contains cation vacancies clustered together in layers which are acting as interfaces between crystallographically ordered regions. The cation vacancy layers may serve as hosts for $\mathrm{Pb}^{2+}$ ions. This model was able to describe the observed nonstoichiometry in a quantitative manner, in agreement with experimental results. Hence, the composition of $\mathrm{PbO}_{2}$ was better written $\left(\mathrm{Pb}^{4+}\right)_{1-x-y}\left(\mathrm{~Pb}^{2+}\right)_{y}\left(\mathrm{O}^{2-}\right)_{2-4 x-2 y}\left(\mathrm{OH}^{-}\right)_{4 x+2 y}$, whereby $x$ designates the cation vacancy fraction and $y$ the fraction of $\mathrm{Pb}^{2+}$ ions present, with respect to the total number of cationic sites.

\subsection{Conductivity}

Critical to its application as an electrode coating is the high conductivity of $\mathrm{PbO}_{2}$. Mindt ${ }^{16}$ reports that the conductivities of $\alpha-\mathrm{PbO}_{2}$ and $\beta-\mathrm{PbO}_{2}$ are close to $10^{3} \mathrm{ohm} \mathrm{m}^{-1} \mathrm{~cm}^{-1}$ and $10^{4} \mathrm{ohm}^{-1} \mathrm{~cm}^{-1}$, respectively, while studies of the Hall effect confirms that conduction results from the movement of electrons. It is widely considered that $\mathrm{PbO}_{2}$ belongs to a group of n-type semiconductors and the conduction band in $\mathrm{PbO}_{2}$ arises, to a first approximation, from the 6 s levels of $\mathrm{Pb}^{4+}$ and the valence band from the $2 \mathrm{p}$ levels of $\mathrm{O}^{2-}$. Possible sources of free electrons in the $\mathrm{PbO}_{2}$ include the deviation from stoichiometry discussed above, the incorporation of protons and the presence of impurities acting as dopants. Other workers suggest that $\beta-\mathrm{PbO}_{2}$ is a metallic conductor. On the basis of self-consistent $a b$ initio calculations of the electronic structure of $\beta-\mathrm{PbO}_{2}$, Heinemann and co-workers ${ }^{28}$ claimed that $\beta-\mathrm{PbO}_{2}$ is a semimetal, with charge-carrier holes in an oxygen $2 p$ band and electrons in a very broad strongly hybridized $\mathrm{Pb} 6 \mathrm{~s}-\mathrm{O} 2 \mathrm{p}$ band. Payne et al. ${ }^{29-31}$ studied the electronic structures of $\alpha-\mathrm{PbO}$ and $\beta-\mathrm{PbO}_{2}$ using X-ray 
photoemission, X-ray absorption and X-ray emission spectroscopies combined with band structure calculations. It is concluded that there is pronounced hybridization between $\mathrm{O} 2 p$ and $\mathrm{Pb} 6 \mathrm{~s}$ and $6 \mathrm{p}$ valence states. The metallic nature of $\mathrm{PbO}_{2}$ is shown to arise from occupation of conduction band states above the Fermi level of stoichiometric $\mathrm{PbO}_{2}$, probably arising from oxygen vacancy defects.

The conductivity of $\beta-\mathrm{PbO}_{2}$ is comparable to metals such as $\mathrm{Ti}$ and $\mathrm{Hg}$ and higher than most forms of carbon. The lower value of conductivity for $\alpha-\mathrm{PbO}_{2}$ could result from several factors including (i) a smaller size of the crystallites in this modification, (ii) a higher carrier density in $\alpha-\mathrm{PbO}_{2}$, leading to a larger number of lattice defects where electrons are scattered, (iii) a high degree of orientation - the (100) axis is perpendicular to the substrate in $\alpha-\mathrm{PbO}_{2}$, (iv) anisotropy of the mobility in $\alpha-\mathrm{PbO}_{2}$, (v) the different crystalline structures of $\alpha-\mathrm{PbO}_{2}$ and $\beta-\mathrm{PbO}_{2}$. Since the difference in the crystal structures results mainly from the different packing of octahedral of similar dimensions, large differences in the band structure and mobility are not expected. ${ }^{16}$

\section{Deposition of lead dioxide}

\subsection{Nucleation and early growth}

The analysis of chronoamperometric responses for the anodic deposition of $\mathrm{PbO}_{2}$ onto platinum surfaces from perchloric acid, nitric acid, and acetate solutions was pivotal to the early development of the theories of nucleation and growth of conducting phases onto inert substrates by Fleischmann and coworkers. ${ }^{32-35}$ These studies led to the concepts of the nucleation of nanocentres of the new phase as the initial step, instantaneous and progressive nucleation, two and three dimensional growth, overlap of growing centres, thickening under electron or mass transfer control. ${ }^{36}$ These studies of the early stages of electrochemical phase formation have been extended using other experimental techniques and to other solutions and substrates by several groups. ${ }^{8,37-42}$

The sequence of chemical steps leading from $\mathrm{Pb}$ (II) in solution to solid lead dioxide has been the subject of much speculation. The most widely quoted mechanism is that proposed by Velichenco et al. ${ }^{43-46}$ involving adsorbed $\mathrm{OH}$ as a key intermediate:

$$
\begin{gathered}
\mathrm{H}_{2} \mathrm{O} \rightarrow \mathrm{OH}_{\mathrm{ads}}+\mathrm{H}^{+}+\mathrm{e}^{-} \\
\mathrm{Pb}^{2+}+\mathrm{OH}_{\mathrm{ads}} \rightarrow \mathrm{Pb}(\mathrm{OH})^{2+} \\
\mathrm{Pb}(\mathrm{OH})^{2+}+\mathrm{H}_{2} \mathrm{O} \rightarrow \mathrm{PbO}_{2}+3 \mathrm{H}^{+}+\mathrm{e}^{-}
\end{gathered}
$$

although the experimental data do not allow easy distinction between possible mechanisms. Several papers using experiments such as a rotating ring-disc electrode have demonstrated that a soluble (or colloidal) lead(Iv) intermediate is involved in both the formation and dissolution of lead dioxide ${ }^{47-51}$ and also the conversion of lead sulfate to lead dioxide. ${ }^{52}$ Again, however, it is uncertain whether the $\mathrm{Pb}$ (IV) species is a short lived intermediate in the major pathway or formed in a minor side reaction.

Ultrasound and microwaves have been shown to have a strong influence on the nucleation of lead dioxide at both vitreous carbon $^{53-59}$ and boron doped diamond electrodes. ${ }^{60,61}$ This phenomenon can be associated with the reaction of $\mathrm{OH}^{\bullet}$ radicals (derived from aqueous sonolysis) with the carbon surface and hence the enhancement of the number of active sites on the surface. Ultrasound and microwaves modify the morphology of the deposit as observed by SEM and can also improve the adherence of the deposit to the substrate.

\subsection{Deposition of lead dioxide coatings}

Many academic papers employ $\mathrm{Pt}, \mathrm{Au}$ or glassy carbon as substrates for the deposition of lead dioxide. Clearly, this is unrealistic for any practical application. Titanium is the usual substrate for applications although an Indian group have promoted graphite ${ }^{62-70}$ and some papers have suggested tantalum ${ }^{71}$ and ebonex. ${ }^{72-74}$ Adhesion of the $\mathrm{PbO}_{2}$ coating to titanium is, however, a problem. Certainly, the titanium, usually in the form of a plate or expanded metal mesh, must be pretreated before the anodic plating process ${ }^{8,75,76}$ in order to remove existing $\mathrm{TiO}_{2}$ scale from the surface and roughen the surface and to prevent passivation. This pretreatment commonly involves, first sandblasting, then an alkaline degrease followed by etching in heated oxalic acid or hydrochloric acid for at least 30 minutes. Even this may be insufficient and various undercoats have been proposed - gold, ${ }^{77}$ platinum, ${ }^{78}$ tin dioxide, ${ }^{47}$ $\mathrm{TiO}_{2} / \mathrm{Ta}_{2} \mathrm{O}_{5}{ }^{79}$ and $\mathrm{TiO}_{2} / \mathrm{RuO}_{2}{ }^{80}$ are examples of such thin undercoats applied to titanium before deposition of the lead dioxide. Another approach has involved the use of multilayers of lead dioxide based materials with different compositions; the bottom layer is selected for good adherence and the top layer for the properties desired for the electrode reaction and/or stability to corrosion in the electrolysis medium. For example (a) Ueda et al. ${ }^{79}$ recommend that the $\mathrm{Ti}$ is first coated with a thermally formed $\mathrm{TiO}_{2} / \mathrm{Ta}_{2} \mathrm{O}_{5}$ undercoat, then a stress free $\alpha-\mathrm{PbO}_{2}$ layer and finally a $\beta-\mathrm{PbO}_{2} / \mathrm{Ta}_{2} \mathrm{O}_{5}$ particle composite. (b) Feng and Johnson ${ }^{81}$ and Mohd and Pletcher ${ }^{82}$ recommend that doped $\mathrm{PbO}_{2}$ coatings on Ti are prepared with an initial layer $\mathrm{F}^{-}$-doped material to give good adhesion and stability and a top layer of $\mathrm{Bi}$ - or Fe-doped lead dioxide to give the desired electrocatalytic activity. Graphite is also degreased and sometimes oxidised and roughened, either mechanically before deposition or, for example, by electroplating from a bath containing fine silica sand. ${ }^{63}$

The literature on the electrochemical deposition of pure lead dioxide is very extensive. It is clear that the adhesion, surface morphology, ratio of $\alpha / \beta$ forms and catalytic activity can be influenced by many parameters including $8,24,46,60,74,83-91$

- the substrate (Pt, Au, graphite, glassy carbon, Ti, Ti with undercoat, Ta).

- pre-treatment of the substrate surface.

- $\mathrm{pH}(1-6$ or $13-14.5)$.

- anion of the electrolyte (nitrate, acetate, hydroxide, methanesulfonate, perchlorate).

- lead(II) concentration (1 mM-1 M).

- current density (1-100 mA cm $\mathrm{m}^{-2}$ ), i.e. rate of deposition.

- potential for deposition, determining the rate of competing reactions, particularly $\mathrm{O}_{2}$ evolution, as well as the rate of $\mathrm{PbO}_{2}$ deposition.

- charge density, i.e. thickness of the deposit. 
- temperature (190-363 K).

- mass transport regime in the plating bath (flow rate, rotation rate, ${ }^{14,55}$ and ultrasound). ${ }^{53-59,65}$

Although many papers consider the influence of deposition conditions on the quality of lead dioxide deposit, it is difficult to draw general conclusions because of (a) the wide variety of conditions and control parameters employed and the subtle dependence of the form and properties of the coatings on the deposition conditions, (b) not all the parameters are controlled or stated in the papers, (c) the morphology and/or ratio of $\alpha / \beta$ forms are stated without experimental data to support the statement. For all these reasons it is difficult to compare results from different laboratories, to draw definitive conclusions about optimum conditions for deposition of a particular type of deposit or to understand the correlation between type of deposit and electrochemical properties.

This can be illustrated with one example. It is widely believed that $\beta-\mathrm{PbO}_{2}$ is deposited from low $\mathrm{pH}$ solutions and $\alpha-\mathrm{PbO}_{2}$ from higher $\mathrm{pH}$ solutions. However, when deposition was carried out from $0.5 \mathrm{M} \mathrm{Pb}\left(\mathrm{CH}_{3} \mathrm{SO}_{3}\right)_{2}+0.5 \mathrm{M} \mathrm{CH}_{3} \mathrm{SO}_{3} \mathrm{H}$ onto vitreous carbon, ${ }^{89-91}$ the ratio of $\alpha / \beta$ forms was found to be strongly dependent on temperature; pure $\alpha-\mathrm{PbO}_{2}$ was formed at $298 \mathrm{~K}$ and pure $\beta-\mathrm{PbO}_{2}$ at $348 \mathrm{~K}$ with both forms deposited at intermediate temperatures. Also the low temperature deposit is compact and shiny and viewed with SEM is smooth on a $10 \mu \mathrm{m}$ scale with crystallites with dimensions of $\sim 50 \mu \mathrm{m}$. In contrast, the $\beta-\mathrm{PbO}_{2}$ deposit is rough by eye and SEM reveals that it is made up of dense overlapping angular crystallites of size $<1 \mu \mathrm{m}$. Such significant changes in structure for a change of temperature of $50 \mathrm{~K}$ emphasises the need to control that parameter closely. In contrast, the variation in the $\alpha / \beta$ ratio with current density or deposition charge was small. In all papers concerning lead dioxide, it is critical that all deposition conditions are fully stated and that the structure of the layer is fully characterised.

Here, it will only be noted that a number of plating baths giving high current efficiency for the formation of $\mathrm{PbO}_{2}$ are known and the conditions that lead to pure $\alpha-\mathrm{PbO}_{2}$ or pure $\beta-\mathrm{PbO}_{2}$ deposits have been defined. For pure $\alpha-\mathrm{PbO}_{2}$, typical conditions are:

(a) saturated lead acetate in $4 \mathrm{M} \mathrm{NaOH}, 298 \mathrm{~K}$, $j=50 \mathrm{~mA} \mathrm{~cm}^{-2}$ then $10 \mathrm{~mA} \mathrm{~cm}^{-2}$;

(b) $0.1 \mathrm{M}$ lead acetate in $1 \mathrm{M}$ sodium acetate, adjusted to pH $5.5,298 \mathrm{~K}, j=10 \mathrm{~mA} \mathrm{~cm}^{-2}$;

(c) $0.5 \mathrm{M}$ lead methane sulfonate in $0.5 \mathrm{M}$ methanesulfonic acid, $298 \mathrm{~K}, j=50 \mathrm{~mA} \mathrm{~cm}{ }^{-2}$;

(d) $0.1 \mathrm{M}$ lead nitrate, $\mathrm{pH} 4.3,298 \mathrm{~K}, j=3.5 \mathrm{~mA} \mathrm{~cm}^{-2}$; and for pure $\beta-\mathrm{PbO}_{2}$ typical conditions include:

(a) $1 \mathrm{M}$ lead nitrate $+0.1 \mathrm{M}$ copper nitrate (to avoid $\mathrm{Pb}$ deposition and nitrate reduction on the cathode) in $1 \mathrm{M}$ nitric acid, $333 \mathrm{~K}, j=50 \mathrm{~mA} \mathrm{~cm}{ }^{-2}$ then $20 \mathrm{~mA} \mathrm{~cm}^{-2}$;

(b) $0.1 \mathrm{M}$ lead nitrate in $1 \mathrm{M}$ nitric acid, $333 \mathrm{~K}$, $j=20 \mathrm{~mA} \mathrm{~cm}^{-2}$;

(c) $1 \mathrm{M}$ lead methane sulfonate in $0.2 \mathrm{M}$ methanesulfonic acid, $333 \mathrm{~K}, j=50 \mathrm{~mA} \mathrm{~cm}^{-2}$.

It is interesting to note that Velichenko and coworkers ${ }^{92}$ recommend that, before use in an electrolysis, the potential of the coating is cycled in sulfuric acid until a steady state voltammogram is observed. It must be expected that the $\mathrm{PbO}_{2}$ structure will change during this potential cycling since the potential range used involves the interconversion $\mathrm{PbO}_{2} / \mathrm{PbSO}_{4}$. Indeed, the influence of potential cycling was earlier investigated by Devilliers et al. ${ }^{74}$ and it was shown the voltammetry provides an approach to monitoring the changes. SEM also clearly shows that the crystallite size decreases substantially.

Even by eye, the deposits can have quite different appearances. It is possible to deposit films with a highly reflective black, metallic finish ${ }^{76,89-91,93}$ although more commonly they have a grey or black matte appearance. When examined by electron microscopy, the diversity of surface morphologies becomes more apparent. Fig. 5 shows SEM images of lead dioxide deposits. It can be seen that the deposits can be made up of crystallites that are very flat, angular, rounded or 'cauliflower' like and their size is another variable. So far there have been few systematic attempts to correlate the structure as shown by SEM with the properties of the deposits. Hyde et al. ${ }^{94}$ used AFM to define a relationship between deposition conditions and structure of deposits on B-doped diamond and sought a correlation between reactivity and structure using the oxidation of glucose as the model reaction. AFM was also used to compare the surface morphologies of deposits from methanesulfonic acid. ${ }^{91}$

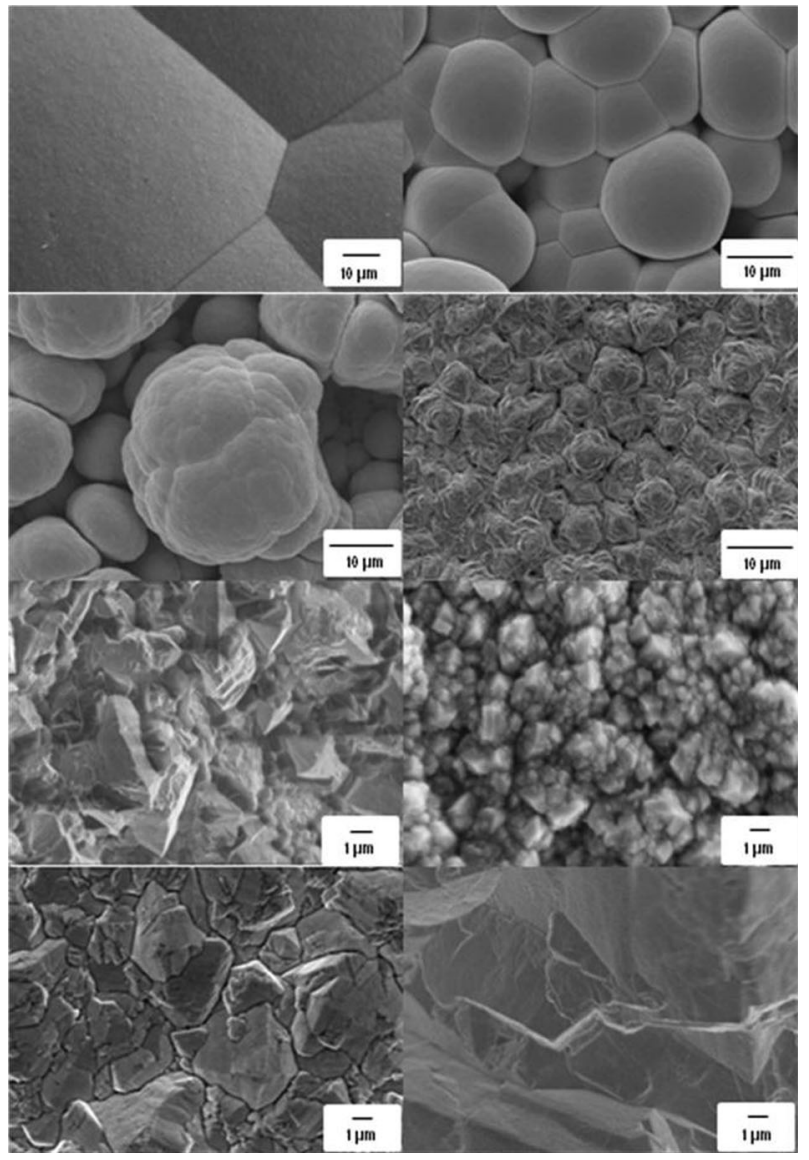

Fig. 5 SEM images of $\mathrm{PbO}_{2}$ deposits with diverse morphologies. All these morphologies resulted from depositions carried out in Southampton using methanesulfonic acid electrolyte. Our thanks are due to Dr I. Sirés who supplied many of these images. 
Following the practices of metal plating, a number of soluble additives have been used to enhance the properties of lead dioxide layers, particularly to improve the adhesion and control the stress. Such organic additives in acid nitrate baths have substantial effects on the $\mathrm{PbO}_{2}$ layer: (a) Teepoll ${ }^{95}$ was found to improve the adherence while creating a higher surface area, (b) triton $\mathrm{X}-100^{96,97}$ improved adhesion and mechanical strength while leading to higher overpotential for $\mathrm{O}_{2}$ evolution, (c) gelatin and sodium dodecylsulfonate ${ }^{97}$ modified morphology and increased the $\alpha-\mathrm{PbO}_{2}$ content of the deposit, (d) polyvinyl pyridine ${ }^{98}$ could be used to control both the morphology and crystal size. Other common additives are long chain, tetraalkylammonium ions ${ }^{99}$ and these have found application in the soluble lead acid battery. ${ }^{89,100-107}$

\subsection{Doped lead dioxide}

The past 20 years have seen much activity focused on the development of doped lead dioxide coatings with improved characteristics (e.g. catalytic activity, adhesion, stability). These doped lead dioxides are simply made by including an additional ion in the plating bath and there is no doubt that large improvements in performance are achieved. But again, the conditions used for the deposition of the doped materials are widely variable. The preparations have frequently involved the depositions from rather dilute solutions of $\mathrm{Pb}$ (II) and similar concentrations of the other ion and high levels of incorporation can be achieved; the ratio of $\mathrm{M}: \mathrm{Pb}$ in the deposit can be $>1$. In other laboratories, the concentration of the other ion is low and the deposit has a dopant level in the $0.1-10 \%$ range. Should the former materials be considered as doped $\mathrm{PbO}_{2}$ or mixed oxides where a major role of the lead dioxide may be as an inert, conducting matrix for a more active oxide? Certainly, in practice, highly doped materials have found greater application.

With each preparation, it needs to be defined whether the other ions are adsorbed, displace $\mathrm{Pb}(\mathrm{IV})$ from the lattice or whether the layer is a mixture of two oxides. Even the oxidation state of the dopant may be uncertain although it is commonly assumed that the elements are in their highest oxidation state. An early paper ${ }^{108}$ concluded that at small dopant levels $(100 \mathrm{ppm})$, the dopant ions increased the $\mathrm{O} / \mathrm{Pb}$ ratio in both $\alpha-\mathrm{PbO}_{2}$ and $\beta-\mathrm{PbO}_{2}$ and generally led to a decrease in the self-discharge rate. Structural studies using X-ray diffractometry of Bi-doped $\mathrm{PbO}_{2}$ showed that the doping did not disturb the rutile structure of pure $\mathrm{PbO}_{2}$ even when the $\mathrm{Bi} / \mathrm{Pb}$ ratio reached 0.7 but there was evidence for an increased orientation of the lattice with respect to the substrate with increasing Bi content; ${ }^{109}$ the average oxidation state of the Bi was estimated as +4.7. Amadelli and coworkers ${ }^{110}$ used SIMS and XPS to investigate the influence of $\mathrm{F}^{-}$and metal ions on the $\mathrm{PbO}_{2}$ films. The fluoride ion was found to be incorporated into the bulk structure and to decrease the extent of adsorbed water. In contrast, the cations (Fe(III), $\mathrm{Co}(\mathrm{II}), \mathrm{Ni}(\mathrm{II})$ ) were not directly detected but were found to influence water accumulation; $\mathrm{Fe}(\mathrm{III})$ caused a decrease in $\mathrm{OH}^{-} / \mathrm{H}_{2} \mathrm{O}$ adsorbed on the surface while $\mathrm{Ni}(\mathrm{II})$ had the opposite effect. More such studies are needed.
Table 1 Doped lead dioxide anodes and the suggested roles for the dopants

\begin{tabular}{lll}
\hline Dopant & Purpose & References \\
\hline $\mathrm{Bi}(\mathrm{III})$ & $\begin{array}{l}\text { Catalyses oxidation of inorganic ions } \\
\text { Catalyses removal TOC }\end{array}$ & $\begin{array}{l}81,82,109,111-115, \\
119-123\end{array}$ \\
& $\begin{array}{l}\text { Reduced fouling by organics } \\
\mathrm{Fe}(\mathrm{III})\end{array}$ & $\begin{array}{l}\text { Catalyses organic oxidation and } \\
\text { TOC removal, also }\end{array}$ \\
& 116,117 \\
& cyanide oxidation & 111 \\
$\mathrm{~F}(-\mathrm{I})$ & Enhances $\mathrm{O}_{3}$ evolution & 123 \\
& Stabilises coating, improves adhesion & $45,88,125$ \\
$\mathrm{As}(\mathrm{III})$ & Inhibits $\mathrm{O}_{2}$ evolution & 126 \\
$\mathrm{Co}(\mathrm{II})$ & Oxidation of organics & 120 \\
$\mathrm{Ag}(\mathrm{I})$ & Catalyses organic degradation & 118 \\
\hline
\end{tabular}

Table 1 summarises some of the dopants used and the specific improvements found. Fluoride ions and Fe(III) have been used effectively to improve the adhesion and the stability of lead dioxide anode coatings while several ions have been demonstrated to catalyse the oxidation of both organic and inorganic species. Bi(III)- and Fe(III)-doped lead dioxides seem to be very general catalysts for oxidations. ${ }^{111}$ Reactions of $\mathrm{Bi}(\mathrm{III})-\mathrm{PbO}_{2}$ reported include the oxidation of $\mathrm{Cr}(\mathrm{III})$ to $\mathrm{Cr}(\mathrm{IV}),{ }^{111-113} \mathrm{Mn}(\mathrm{II})$ to $\mathrm{Mn}(\mathrm{III}),{ }^{11,114}$ cyanide, ${ }^{111}$ thiophen derivatives $^{11,114}$ and dimethyl sulfoxide. ${ }^{11,114}$ A number of these papers describe quantitative comparisons of the kinetics of oxidation at doped and undoped lead dioxide anodes; doping can lead to an increase in the rate of oxidation by a factor $>100$ and, indeed, transform a surface where reaction is minimal to one where the reaction is mass transfer controlled. Fig. 6 illustrates such catalysis using the example of cyanide ion oxidation at undoped and Fe-doped $\mathrm{PbO}_{2} \cdot{ }^{111}$ At the undoped $\mathrm{PbO}_{2}$, the cyanide is only oxidised at a very low rate. At the Fe-doped $\mathrm{PbO}_{2}$, well formed oxidation waves are observed and the current at $+1.4 \mathrm{~V}$ can be seen to be proportional to the square route of the rotation rate confirming that the

a E (V vs. SCE)

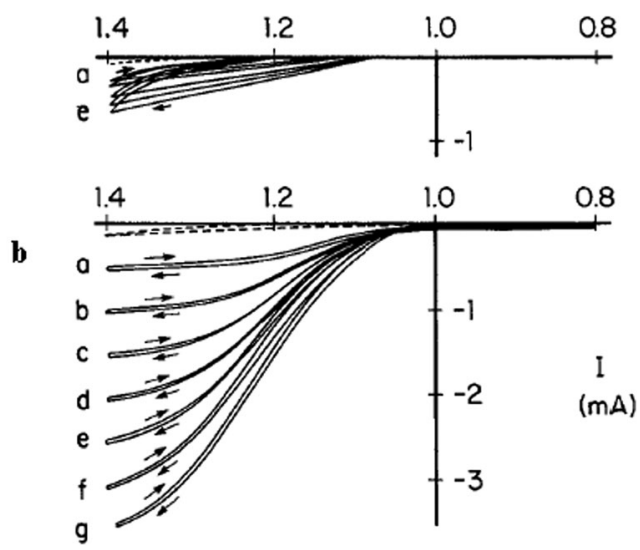

Fig. 6 Rotating disc voltammograms for the oxidation of $5 \mathrm{mM}$ $\mathrm{NaCN}$ in aqueous $\mathrm{NaHCO}_{3} / \mathrm{Na}_{2} \mathrm{CO}_{3}$, pH 10 at (a) undoped $\mathrm{PbO}_{2}$ and (b) $\mathrm{Fe}-\mathrm{PbO}_{2}$ coatings on an $\mathrm{Au}$ rotating disc electrode. Rotation rates in revolutions per minute (a) 100, (b) 400, (c) 900, (d) 1600, (e) 2500, (f) 3600, (g) 4900 . The dashed responses are for the electrolyte in the absence of NaCN. ${ }^{111}$ Reproduced by permission of The Electrosynthesis Company Inc. 
oxidation is mass transfer controlled. The product from the oxidation of cyanide is cyanate. ${ }^{111}$ In view of the high rates of oxidation of organics at some doped coatings, it is not surprising that the studies have been extended to the complete oxidation of organics and hence for the removal of TOC/COD from effluent mimics. ${ }^{115-118}$

Johnson and coworkers ${ }^{109,111,112,114-116,119,120,124,127}$ have made detailed studies of the mechanisms for the enhancement of rates by doping. They regard oxidations at lead dioxide anodes as oxygen transfer reactions rather than electron transfer reactions and therefore stress the importance of the activation of water as adsorbed $\mathrm{OH}$ radicals as the key step in the oxidations. In addition, it was considered that pre-adsorption of the molecule/ion to be oxidised may also be important. Low additions of $\mathrm{Bi}(\mathrm{a} \mathrm{Bi} / \mathrm{Pb}$ ratio $<0.1)$ can be effective in increasing the rate of oxidations ${ }^{109}$ and similar enhancements can be achieved by adsorption of $\mathrm{Bi}$ (III) onto a preformed $\mathrm{PbO}_{2}$ layer. ${ }^{120}$ It is suggested that the $\mathrm{Bi}(\mathrm{v})$ sites promote the formation of adsorbed $\mathrm{OH}$ radicals. In contrast, it is proposed that the major influence of transition metals such as Fe(III) is to enhance the adsorption of the organic molecule or inorganic ion to be oxidised. ${ }^{111}$ It cannot be ruled out, however, that some metal ions, e.g. Fe(III), Ag(I), may catalyse oxidations by undergoing a change in oxidation state. Finally, anion dopants are considered to disrupt the structure of the $\mathrm{PbO}_{2}$ lattice, thereby enhancing the formation of adsorbed $\mathrm{OH}$ radicals. ${ }^{111}$

The ability to tailor coating performance through doping has also led to the fabrication of improved anodes with a layered structure. The first layer is generally fluoride doped to enhance adhesion and stability while the top layer is, for example, $\mathrm{Bi}(\mathrm{III}),{ }^{81} \mathrm{Fe}(\mathrm{III}){ }^{117}$ or $\mathrm{Co}(\mathrm{II})^{118}$ doped to increase the rate of oxidation.

\subsection{Nano- and microstructured deposits}

The fabrication of nanostructured materials has become an important activity ${ }^{128,129}$ in modern research; in electrochemistry, the main objective has been to increase surface area and hence the rate of reactions.

Two papers ${ }^{130,131}$ report the formation of $\mathrm{PbO}_{2}$ nanowires by electrodeposition into commercial anodic alumina membranes with mean pore diameters of $\sim 210 \mathrm{~nm}$. The deposition were carried out using a nitrate bath, with $\mathrm{pH}$ being used to control whether $\alpha$ - or $\beta-\mathrm{PbO}_{2}$ or $\alpha / \beta$ mixtures are formed. After the deposition, the alumina membrane is dissolved in sodium hydroxide to give free standing clusters of $\mathrm{PbO}_{2}$ nanowires, see Fig. 7(a). Bartlett et al. ${ }^{132}$ describe deposition of $\mathrm{PbO}_{2}$ into self-assembled, close-packed arrays of polystyrene microspheres (diameters $500 \mathrm{~nm}$ or $750 \mathrm{~nm}$ ), followed by dissolution of the polystyrene microspheres with organic solvent to give a highly regular structure that depends on the thickness of the deposit compared to the diameter of the microspheres. Fig. 7(b) shows a relatively thin layer where deposition of $\mathrm{PbO}_{2}$ stops before a monolayer of the polystyrene microspheres is covered while Fig. 7(c) shows the foam-like deposit when deposition is carried out into multilayers of the microspheres.

The above papers describe highly ordered layer structures. The potential advantage of a high area surface has led to other

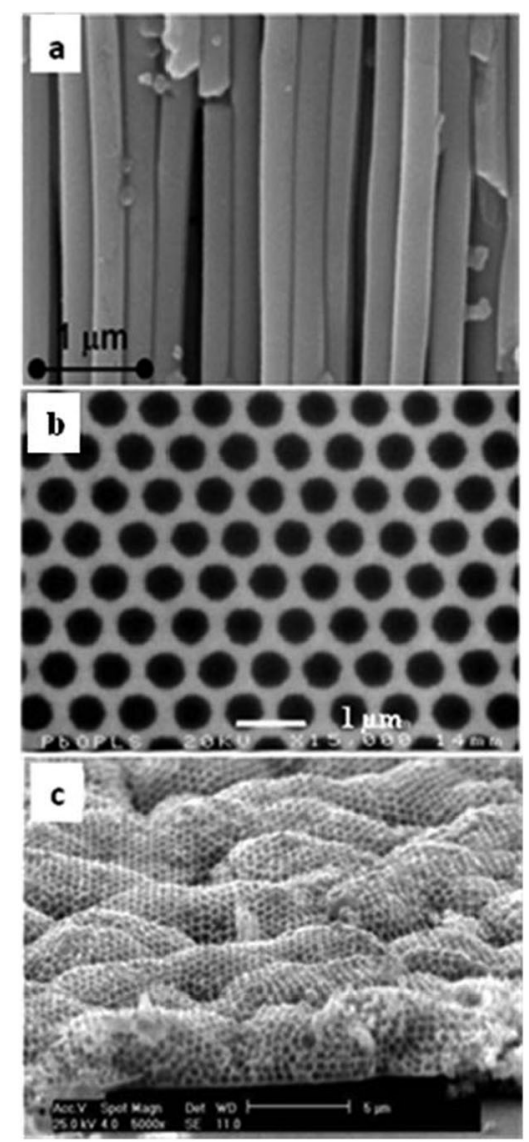

Fig. $7 \mathrm{SEM}$ images of (a) $\beta-\mathrm{PbO}_{2}$ nanowires deposited into an alumina membrane after dissolution of the membrane. ${ }^{130}$ Reproduced by permission of The Electrochemical Society. (b) A macroporous $\alpha-\mathrm{PbO}_{2}$ film grown into a template consisting of a monolayer of $750 \mathrm{~nm}$ diameter polystyrene spheres after dissolution of the microspheres. ${ }^{132}$ (c) A thick macroporous $\beta-\mathrm{PbO}_{2}$ film deposited into a template consisting of multilayers of $500 \mathrm{~nm}$ diameter polystyrene spheres after dissolution of the microspheres. ${ }^{132}$ Reproduced by permission of The Royal Society of Chemistry.

approaches to modifying electrodeposited $\mathrm{PbO}_{2}$ layers. The strong dependence of surface morphology on the deposition conditions was highlighted in Section 3.2 above and these represent quite different areas of the $\mathrm{PbO}_{2}$ /solution interface. Two approaches to the creation of high surface area layers should be mentioned here. Blood et al. ${ }^{133}$ describe deposition from a high internal phase emulsion (HIPE); this is an emulsion of the aqueous electrolyte containing $\mathrm{Pb}$ (II) with a mixture of unsaturated organic compounds (precursors to HIPE polymers). The lead dioxide layer formed by electrodeposition from the HIPE was composed of pyramidal features pitted with a large number of pores with diameters in the range $0.5-2 \mu \mathrm{m}$, see Fig. 8. In another approach, Ghasemi et al. ${ }^{134,135}$ used pulsed current to create featured surfaces.

In these papers, the focus was on increasing the charge density of the positive electrode in lead acid batteries. This seems a poor choice since the repeated $\mathrm{PbO}_{2} / \mathrm{PbSO}_{4}$ interconversion makes probable the degradation of the nanostructure. There must also be a concern about the stability of very high 


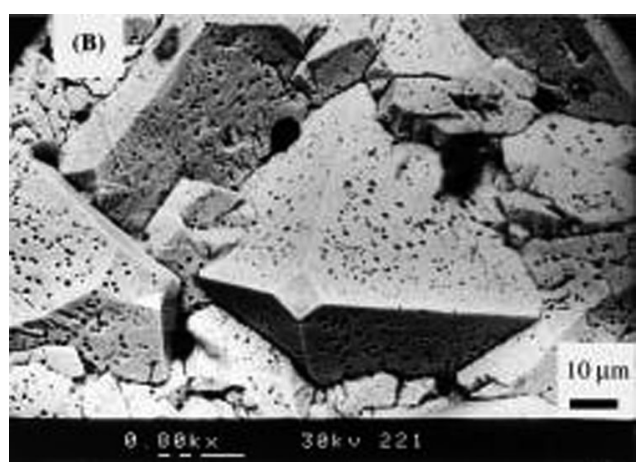

Fig. 8 SEM image of a $\mathrm{PbO}_{2}$ electrodeposit produced at $3.2 \mathrm{~mA} \mathrm{~cm}^{-2}$ for $21600 \mathrm{~s}$ from a high internal phase emulsion on a carbon rod electrode substrate. ${ }^{133}$ Reproduced by permission of Springer.

area structures in contact with aqueous acids since the rate of the $\mathrm{PbO}_{2}$ /water reaction must be increased.

\subsection{Composites}

Composites are electrodeposits containing solid particles to introduce or enhance specific properties to the coating and are formed by deposition from baths containing dispersions of micro- or nano-sized particles and usually a surfactant. In general, composites in metal electroplates have been used to introduce/improve strength, wear resistance, corrosion resistance, self-lubrication, catalytic activity and other properties. ${ }^{136-138}$ A substantial number of lead dioxide composites have now been prepared and tested, see Table 2. The depositions are carried out in a variety of baths and with particulates with dimensions $<1 \mu \mathrm{m}$. The particulate content of the deposit initially increases with the particulate content of the plating bath but usually reaches a limit. It also depends on other control parameters such as current density and the mass transport regime.

Table 2 Lead dioxide composites-particulate constituents and the target property to be enhanced

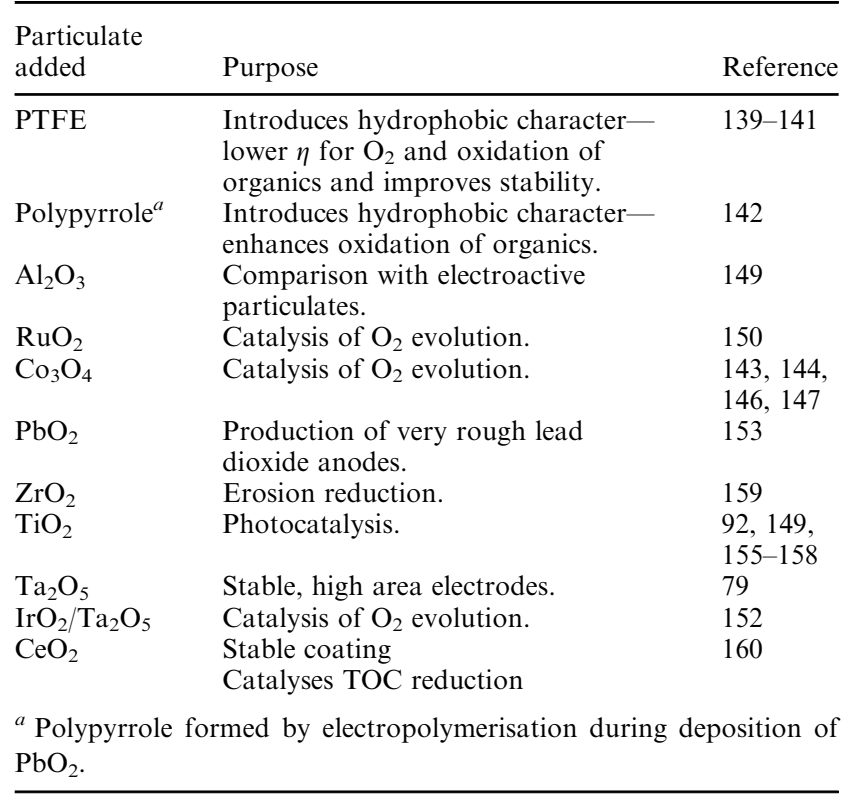

Polymeric materials such as PTFE ${ }^{139-141}$ and polypyrrole ${ }^{142}$ were thought to introduce hydrophobicity and therefore both assist the release of gases and aid the interaction of organic molecules with the $\mathrm{PbO}_{2}$ surface. The PTFE was also thought to reduce stress and thereby increase adhesion to the carbon substrate.

Musiani's group ${ }^{143-154}$ have sought to produce new electrocatalysts for the oxygen evolution reaction and other electrochemical oxidation processes essentially using the $\mathrm{PbO}_{2}$ as a stable, conducting matrix to encapsulate particles that are more active catalysts for $\mathrm{O}_{2}$ evolution and other reactions. They have studied composites with both electrocatalytic and inactive particulates and some particulates also enhanced the conductivity and/or mechanical strength of the $\mathrm{PbO}_{2}$ matrix. Interestingly, co-deposition of conductive particles led to much rougher surface morphologies for the $\mathrm{PbO}_{2}$ matrix while non-conducting particles, e.g. $\mathrm{Al}_{2} \mathrm{O}_{3}$ and $\mathrm{TiO}_{2}$, did not influence its morphology. ${ }^{149}$ Rough anodes could also be produced using $\mathrm{PbO}_{2}$ particulates in a $\mathrm{PbO}_{2}$ matrix. ${ }^{153}$ The roughness is, of course, a favorable feature for electrocatalysis.

$\mathrm{Co}_{3} \mathrm{O}_{4}$ was the preferred particulate for $\mathrm{O}_{2}$ evolution. $\mathrm{PbO}_{2} / \mathrm{Co}_{3} \mathrm{O}_{4}$ composite electrodes exhibit much lower overpotentials and Tafel slopes ${ }^{143,147}$ in both acidic and basic media compared to pure $\mathrm{PbO}_{2}$. Prolonged electrolysis tests confirmed good stability of the composites (no degradation was observed at room temperature during several weeks at an imposed current density of $100 \mathrm{~mA} \mathrm{~cm}^{-2}$ ), although a weakness of these composites was the tendency to undergo detachment from the underlying substrate when submitted to electrolysis at high temperature. ${ }^{144,145} \mathrm{PbO}_{2}$ was also shown to be a superior matrix than $\mathrm{Pb}$ or $\mathrm{Ni}$ for the $\mathrm{Co}_{3} \mathrm{O}_{4} \cdot{ }^{146} \mathrm{PbO}_{2} / \mathrm{RuO}_{2}$ composite electrodes also exhibited catalytic activity for oxygen evolution reaction, in fact comparable to that of thermally prepared $\mathrm{Ti} / \mathrm{RuO}_{2}$ electrodes. ${ }^{150,151}$ In practice, however, in acid, reduction of the $\mathrm{PbO}_{2}$ to give $\mathrm{Pb}^{2+}$ in solution or an insoluble salt (depending on the acid) occurred at the potential for $\mathrm{O}_{2}$ evolution and the composite was also subject to open circuit corrosion. $\mathrm{PbO}_{2} / \mathrm{IrO}_{2} / \mathrm{Ta}_{2} \mathrm{O}_{5}$ composites were more stable but gave a higher overpotential for $\mathrm{O}_{2}$ evolution. ${ }^{152}$

Recently, the $\mathrm{PbO}_{2} / \mathrm{TiO}_{2}$ composites have attracted considerable attention due to their potential application in photoelectrocatalytic oxidation of organics in wastewater. ${ }^{92,155-158}$ Qu et al. ${ }^{155,156}$ reported the electrochemically assisted photocatalytic degradation of Acid Orange 7 and an azo-dye Orange II using the $\mathrm{PbO}_{2} / \mathrm{TiO}_{2}$ composite electrodes. The degradation efficiencies improved slightly with the $\mathrm{TiO}_{2}$ content and with increase in potential. Jin et al. ${ }^{157}$ utilized the $\mathrm{PbO}_{2} / \mathrm{TiO}_{2}$ composite electrode as an amperometric sensor to determine the chemical oxygen demand of waste waters. The method had a low detection limit and wide application range and the COD values compared well with determinations by a traditional method. Velichenko et al. ${ }^{92,158}$ examined the mechanism of $\mathrm{PbO}_{2}$ electrodeposition in the presence of colloidal suspension of small $\mathrm{TiO}_{2}$ nanoparticles, mean diameter of $5 \mathrm{~nm}$. They concluded: (i) addition of $\mathrm{TiO}_{2}$ nanoparticles to the electrolyte leads to enhancement of the rate of $\mathrm{PbO}_{2}$; (ii) the mechanism is essentially the same as observed in the absence of $\mathrm{TiO}_{2}$; (iii) the key aspect in this mechanism is the role of $\mathrm{OH}^{\bullet}$ radicals formed from the discharge of water; (iv) the service life of 
the composite during the photo-electrocatalytic oxidation of oxalic acid and benzyl alcohol was a factor of $\sim 3$ longer than traditional $\mathrm{PbO}_{2}$ anodes.

\section{Applications}

Lead dioxide anodes based on both lead/lead alloy substrates and inert substrates, particularly carbon and titanium, have found diverse applications. The former are generally formed in situ in the process conditions when the electrolyte for the process contains an anion leading to an insoluble and 'protective' $\mathrm{Pb}$ (II) layer on the lead surface. As with the plated layers, the $\mathrm{PbO}_{2}$ may be $\alpha$ - or $\beta$-phase or mixtures of the two depending on the oxidation conditions. ${ }^{161}$ On inert substrates, $\beta$-lead dioxide anodes are available from a number of suppliers worldwide but, commonly, literature reports employ 'home manufactured' coatings. Both approaches lead to uncertainties in interpreting and comparing results. As discussed in the previous section, the form (and presumably performance), including the lifetime, of lead dioxide coatings depends strongly on the deposition conditions; the conditions for the fabrication of the commercial coated anodes are never specified while the academic community have used a variety of preparative conditions (and some papers do not always fully specify them). In all applications, the use of lead dioxide anodes is dependent on a demonstration that the 'electrolyte' is not significantly contaminated by lead(II); the stability of the lead dioxide coating may be dependent on the nature and concentration of all components in the medium as well as the fabrication procedure and operating parameters.

\subsection{Oxygen evolution as a counter electrode reaction}

Lead dioxide anodes formed in situ in sulfuric acid on lead/lead alloy substrates have been widely used as oxygen evolving counter electrodes for processes employing a sulfuric acid electrolyte free of halide ions. ${ }^{1,8,162}$ The biggest application is the electrowinning of copper although similar technology is used for other metals such as zinc, nickel and chromium. ${ }^{1}$ The technology is simple and designed to permit easy removal of the metal after deposition on the cathode. The metals are refined in open tank cells with parallel, alternate lines of cathode and anode plates; for copper, the tanks are similar in size to a swimming pool and each anode plate is a fraction of a square metre. The anode current density is generally in the range $10-100 \mathrm{~mA} \mathrm{~cm}{ }^{-2}$. The anode material is a lead alloy with $6-15 \% \mathrm{Sb}$ and $0-1 \% \mathrm{Ag}$. The antimony hardens the alloy and improves its mechanical properties while the silver reduces the overpotential for oxygen evolution and hence the energy consumption for the process. In the process operating conditions, the anodes have an easily seen corrosion coating but with careful handling have a lifetime of several years. For the past 30 years, these lead anodes have received competition from DSA coatings ( $\mathrm{Ti} / \mathrm{IrO}_{2}$ based dimensionally stable anodes), but the low cost and acceptable performance of the lead dioxide leads to their retention in many plants.

Another process that used a $\mathrm{PbAg}$ alloy anode in a sulfuric acid anolyte was the first version of the Monsanto process for the hydrodimerisation of acrylonitrile to adiponitrile. ${ }^{1}$ This process employed divided, parallel plate cells in a bipolar stack. The catholyte was a complex mixture of organics and a proton permeable membrane was used to separate it from the anolyte and hence maintain a clean sulfuric acid anolyte. In these conditions, the lead dioxide anodes could maintain a current density of $450 \mathrm{~mA} \mathrm{~cm}^{-2}$. For reasons unassociated with the lead alloy anodes, in the 1980s this technology was modified to allow operation with an undivided cell and the anodes are now steel.

\subsection{The manufacture of chemicals}

Lead dioxide anodes have been extensively employed in the manufacture of peracids, their salts and strong oxidising agents and, in many cases, electrolysis is the only route for their manufacture. All such processes require high positive potentials and the only alternative anode material is the expensive $\mathrm{Pt} / \mathrm{Ti}$.

Over the past 50 years, perchlorates have been manufactured by the anodic oxidation of the corresponding chlorate and plants in the USA, Japan, Europe and India have used $\mathrm{PbO}_{2}$ coated graphite or titanium anodes; $;{ }^{8,12,62-70,162-164}$ the most detailed discussion of process conditions come from the Indian group led by Udupa. ${ }^{62-67}$ Typical conditions are an electrolyte consisting of $250 \mathrm{~g} \mathrm{litre}^{-1}$ of the chlorate, $\mathrm{pH} 7$, at a temperature of $\sim 330 \mathrm{~K}$, a $\mathrm{PbO}_{2}$ anode and a steel cathode and a current density of $50 \mathrm{~mA} \mathrm{~cm}{ }^{-2}$. The current efficiency is $>80 \%$ with an energy consumption of $6.0-6.5 \mathrm{kWh} \mathrm{kg}^{-1}$ of the perchlorate. Similar technology for the production of periodate has been described ${ }^{62}$ and processes have also been described for the formation of bromate ${ }^{165}$ and iodate ${ }^{62}$ from bromide and iodide, respectively.

Lead dioxide anodes have also been used for the production of strong oxidising agents such as dichromate, ${ }^{78,111-113,166-168}$ manganese (III) ${ }^{109,114,119,169,170}$ and cerium(IV). ${ }^{169-172}$ Most commonly, these processes are used to regenerate the spent oxidising agent from the oxidation of organic compounds (e.g. anthracene, naphthalene, montan wax), etchants and polishing/plating baths and are therefore operated on a wide variety of scales. Technology based on parallel plate, membrane cells is now common and both lead and inert substrate based anodes have been employed. For example, the plant for the regeneration of chromic acid used for the conversion of anthracene to anthraquinone ${ }^{168}$ required the regeneration of chromic acid by the oxidation of $\mathrm{Cr}(\mathrm{III})$ in a medium containing $\sim 40-150 \mathrm{~g}^{\text {litre }}{ }^{-1}$ of $\mathrm{Cr}$ (III) in sulfuric acid. The cells used $1 \mathrm{~m}^{2}$ bipolar electrodes with lead anode and steel cathode surfaces and these were arranged in a bipolar stack of 39 cells with Nafion ${ }^{\mathrm{TM}}$ membrane separators. The current density was $150 \mathrm{~mA} \mathrm{~cm}^{-2}$ and although anode corrosion occurred, the use of lead anodes several millimetres thick allowed continuous operation for several years. For the regeneration of chromic acid there are probably no alternatives to $\mathrm{PbO}_{2}$ as the anode material. Pletcher and Tait ${ }^{167}$ investigated the influence of the lead surface oxidation on the kinetics of $\mathrm{Cr}(\mathrm{III})$ oxidation.

For an extended period, the Miles Chemical Co in the USA ran a 45 ton year $^{-1}$ plant for the manufacture of dialdehyde starch with integrated electrolytic regeneration of periodate. ${ }^{173}$ The technology employed $\mathrm{PbO}_{2}$ anodes. 


\subsection{The generation of ozone}

Ozone is an environmentally friendly oxidant with applications in the purification and sterilization of water, paper bleaching, oxidation, deodorization, and decolorization of waste water. ${ }^{174,175}$ It has, however, a very short half life and must be generated on site at the time of use. The conventional way to produce ozone is based on cold corona discharge (CCD) technology where dry oxygen or air is flowed past an electric discharge, producing a $2-3 \%$ concentration of ozone in air. The overall energy consumption of the CCD process is high because cooling and drying of air are needed in addition to a high voltage discharge. Electrochemical ozone generation has considered as an attractive alternative since the 1970s. ${ }^{124,126,176-202}$ Compared to the CCD technology, electrochemical ozone generation has several advantages; for example it can produce a higher in situ ozone concentration without by-product and secondary pollution.

The electrolytic production of ozone requires a high positive potential (the formal potential for the $\mathrm{O}_{3} / \mathrm{H}_{2} \mathrm{O}$ couple is $+1510 \mathrm{mV}$ ) and it is always produced alongside copious oxygen evolution. Hence, the current efficiency is the major factor determining energy consumption and inhibition of $\mathrm{O}_{2}$ is clearly an advantage. The anodic generation of ozone at lead dioxide anodes has been reported in several aqueous media including neutral sodium sulfate, ${ }^{176}$ perchloric acid, ${ }^{178,179}$ phosphoric acid, ${ }^{177,182}$ neutral phosphate, ${ }^{180}$ sulfuric acid, ${ }^{182}$ and fluoroboric acid; ${ }^{182}$ the current efficiencies vary in the range $3-18 \%$. The electrolyses are run at high current densities, $600-1200 \mathrm{~mA} \mathrm{~cm}^{-2}$ and the current efficiencies are higher in acids at lower temperatures. It has also been reported that the addition of fluoride or anions containing fluoride to the electrolyte improves the current efficiency ${ }^{124,182,186,192-194}$ and $\beta-\mathrm{PbO}_{2}$ doped with $\mathrm{Fe}$ or $\mathrm{F}$ also perform better than undoped $\mathrm{PbO}_{2}{ }^{124,195}$ Because of the very positive potentials essential to ozone generation, the only alternatives to lead dioxide is vitreous carbon and diamond. Yields as high as 45\% have been reported for vitreous carbon in $62 \mathrm{wt} \% \mathrm{HBF}_{4}$ at low temperatures ${ }^{181-184}$ but lead dioxide is more flexible in cell design and the low cost choice.

Da Silva et al. ${ }^{196-200}$ emphasize that in addition to the composition of the $\mathrm{PbO}_{2}$ used for ozone generation, the electrode morphology (e.g. porosity, roughness) also strongly influences ozone generation kinetics and current efficiency. In the case of more compact coatings the fluoroanions cause a substantial effect on the current efficiency of ozone over the complete current interval investigated while with less compact coatings the influence of the fluoroanions is mainly verified at current density less than $0.3 \mathrm{~A} \mathrm{~cm}^{-2}$. This result emphasizes the need for a detailed investigation of the electrode preparation parameters in order to optimise current efficiency and reach a better understanding of the fundamental aspects involved. Foller and Tobias ${ }^{182}$ also mentioned that different $\mathrm{PbO}_{2}$ surfaces can show remarkable variation in ozone yield and found it necessary to chemically etch $\mathrm{PbO}_{2}$ electrodes with hydrogen peroxide and acetic acid before each use in order to obtain reproducible results.

A significant advance in electrolytic ozone generation technology was accomplished by Stucki and co-workers. ${ }^{188-192}$
They developed a novel, zero gap electrolytic ozone generator using a solid, proton conducting polymer electrolyte $\left(\right.$ Nafion ${ }^{\mathbb{R}}$ )

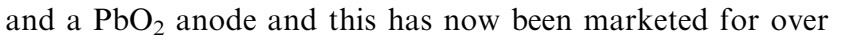
20 years under the tradename Membrel ${ }^{\circledR}$. It is designed for the disinfection and purification of water and hence to supply ultra pure water to, for example, the pharmaceuticals, fine chemicals, electronics and the food supply industries. The core to the system is an electrolytic cell where the $30 \mathrm{~cm}^{2}$ electrodes are pressed up against the Nafion ${ }^{\mathbb{B}}$ membrane to form an 'MEA type' structure. The anode material is porous, sintered titanium coated with $\mathrm{PbO}_{2}$ and the cathode is a porous stainless steel structure coated with Pt. This zero gap configuration improves the stability of the $\mathrm{PbO}_{2}$ anode (by preventing erosion from solution flow and by avoiding $\mathrm{pH}$ gradients at the electrode surfaces that would result from the high operating current density in liquid electrolytes) and allows water (with no added electrolyte) to be fed to the back of the anode and electrolyzed to produce a mixture of $\mathrm{O}_{2}$ and $\mathrm{O}_{3}$ on the backside of the anode and $\mathrm{H}_{2}$ on the cathode. In a high pressure format, the ozone exits the cell as a highly concentrated solution of ozone, $>100 \mathrm{mg}$ litre $^{-1}$; otherwise it leaves as a gas. The cell is operated at a current density of $0.5-2 \mathrm{~A} \mathrm{~cm}^{-2}$ with a cell voltage of 3-5 V. This gives a current efficiency of $\sim 20 \%$ and an energy consumption of $65 \mathrm{Wh} \mathrm{g}^{-1}$. Membrel ${ }^{\circledR}$ is marketed in units capable of delivering $1 \mathrm{~g} \mathrm{hour}^{-1}, 3 \mathrm{~g} \mathrm{hour}^{-1}$ or $9 \mathrm{~g} \mathrm{hour}^{-1}$ of ozone and the units are said to operate continuously for over 3 years without major maintenance.

Onda et $a .^{201}$ also operated a solid polymer electrolyte electrolysis cell but used an anode structure with several layers of $\mathrm{PbO}_{2}$ coated titanium mesh with different mesh dimensions. The finest mesh was placed against the membrane. The authors claim that this cell design produces exit water with a $\mathrm{Pb}$ (II) content more than a factor of 100 below the allowable level for drinking water. Hence, this modified design can be used for the sterilization of drinking water.

Ozone electrogenerated at $\mathrm{PbO}_{2}$ has been shown to be effective for the destruction of a wide range of organics including trans-3,4-dihydroxycinnamic acid, ${ }^{202}$ phenols, ${ }^{195}$ reactive dyes. ${ }^{200}$ Amadelli and coworkers ${ }^{202}$ suggest that the most effective way to use the ozone is to feed it to a hydrogen peroxide forming cathode since this generates a very high concentration of free radicals. The ozone output also kills many germs, etc.

\subsection{Water and effluent treatment}

With increasing social and legislative pressures to ensure that effluents are fully treated before discharge into rivers, lakes or the sea, there have been extensive studies of the electrolytic mineralisation of organic compounds with a particular focus on compounds that are toxic or resistant to biological treatments. ${ }^{11,203-206}$ It is widely believed that complete mineralisation occurs by mechanisms dominated by oxygen transfer and adsorbed or free $\mathrm{OH}$ radicals rather than direct electron transfer from the organics to the anode..$^{71,207,208}$ This requires anodes that are stable at very positive potentials; lead dioxide and B-doped diamond have proved the most suitable materials. In general, B-doped diamond gives the highest rate of mineralisation but such anodes are expensive and doubts remain about their long term stability. This presents opportunities for lead 
dioxide. Particularly in water and effluent treatment, the absence of $\mathrm{Pb}$ (II) contamination of the medium must clearly be demonstrated.

There have been many studies of the mechanisms for the degradation of organics at lead dioxide anodes using electrochemical, spectroscopic and intermediate product identification. ${ }^{71,88,111,203-215}$ The most compelling evidence for a role for $\mathrm{OH}$ radicals comes from the use of spin trapping agents $^{88,209-212}$ but many of the steps in the complex reaction sequences remain speculation. There is also good evidence that doping the electrodeposited $\mathrm{PbO}_{2}$ layer with elements such as $\mathrm{Bi}(\mathrm{III}), \mathrm{Fe}(\mathrm{III})$ and $\mathrm{F}^{-}$accelerates oxidation, leads to more complete mineralisation and/or enhances the stability of the coating. ${ }^{81,86,117,121-126,216-222}$ It has also been reported that there are distinct differences in the performance of $\alpha$ - and $\beta-\mathrm{PbO}_{2}{ }^{223}$ and morphologies ${ }^{224}$ of the lead dioxide surfaces.

The degradation of a large number of organic pollutants has been reported. These include phenol, ${ }^{71,118,121,122,216,217,222-232}$ aniline, ${ }^{233}$ benzoquinone, ${ }^{116,218}$ chlorinated phenols, ${ }^{87,219-221}$ nitrophenol, ${ }^{86,222,234,235}$ naphthol, ${ }^{236}$ glucose, ${ }^{237,238}$ oxalic acid, ${ }^{239,240}$ chloranilic acid, ${ }^{241}$ indoles, ${ }^{242}$ tannic acid, ${ }^{243}$ 1,2-dichloroethane, ${ }^{244}$ cresols, ${ }^{245}$ herbicides, ${ }^{246,247}$ pesticides, ${ }^{248}$ surfactants $^{249}$ and dyes. ${ }^{82,117,250,251}$ Substantial diminution of $\mathrm{COD} / \mathrm{TOC}$ is generally possible with an acceptable current efficiency. Such studies, however, generally use electrolytes and $\mathrm{pH}$ conditions seldom found in real effluents and are satisfied with low current densities that would be unacceptable to industrial practice. The lead dioxide anodes need to be incorporated into realistic cell designs in order to give acceptable rates of mineralisation and to examine anode lifetimes with the real process streams in operating conditions.

Far fewer papers have considered the treatment of real effluents. Examples would include urine biomass, ${ }^{252}$ landfill leachate, ${ }^{253-255}$ tannery waste, ${ }^{243}$ waste water, ${ }^{122,237}$ phenol streams, ${ }^{121,122}$ dye plant effluents ${ }^{117}$ and herbicide manufacture effluents. ${ }^{246,247}$ Good levels of COD/TOC removal have been achieved although generally with rather poor current efficiency. In most cases, however, these effluents also contain chloride and this broadens the possible chemistry of the degradations with likely roles for chlorine, hypochlorous acid, etc. and hence to mechanisms not normally discussed in the academic literature.

\subsection{The soluble lead(II) acid flow battery}

A group in Southampton have been developing a novel flow battery intended for large scale energy storage. ${ }^{14,89,100-107,256}$ The overall cell chemistry is

$$
2 \mathrm{~Pb}^{2+}+2 \mathrm{H}_{2} \mathrm{O} \underset{\text { discharge }}{\stackrel{\text { charge }}{\rightleftarrows}} \mathrm{Pb}+\mathrm{PbO}_{2}+4 \mathrm{H}^{+}
$$

and the electrolyte is methanesulfonic acid in which $\mathrm{Pb}$ (II) is highly soluble. The advantage of the system is that it requires only a single electrolyte and hence no membrane. Unlike other flow batteries the energy is stored as deposits on the two electrodes. Hence, the battery requires the electrodeposition and cathodic dissolution of thick layers of lead dioxide at the positive electrode (as well as thick layers of lead metal at the negative electrode). In some conditions it is possible to deposit thick and uniform lead dioxide layers from the methanesulfonic

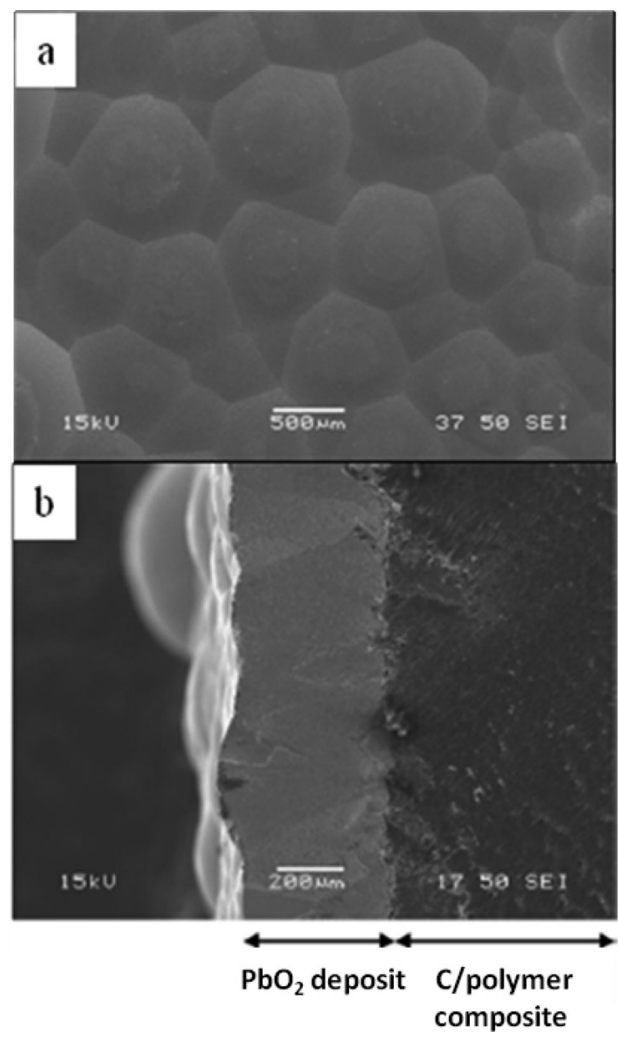

Fig. 9 SEM images of (a) the surface and (b) a cross section of a thick $\mathrm{PbO}_{2}$ deposit grown from a solution of $0.5 \mathrm{M} \mathrm{Pb}\left(\mathrm{CH}_{3} \mathrm{SO}_{3}\right)_{2}+0.3 \mathrm{M}$ $\mathrm{CH}_{3} \mathrm{SO}_{3} \mathrm{H}+5 \mathrm{mM} \mathrm{C}_{16} \mathrm{H}_{33}\left(\mathrm{CH}_{3}\right)_{3} \mathrm{~N}^{+}$at $50 \mathrm{~mA} \mathrm{~cm}^{-2}$ at $298 \mathrm{~K}$ on a carbon polymer composite electrode. ${ }^{256}$ Reproduced by permission of The Electrochemical Society.

acid medium at quite high rates, see Fig. 9 and this can be discharged with good current efficiency. Indeed, it is possible to cycle the battery more than 100 times with an energy efficiency of $\sim 70 \%$ but failure eventually occurs led by incomplete dissolution of the lead dioxide. This incomplete dissolution is probably associated with an increase in $\mathrm{pH}$ within the pores of thick layers of lead dioxide. The preferred form of the lead dioxide is $\alpha-\mathrm{PbO}_{2}$; only $\alpha-\mathrm{PbO}_{2}$ is formed during the initial charge periods but, on continuous cycling, eventually a mixture of $\alpha$ - and $\beta-\mathrm{PbO}_{2}$ is deposited and this may contribute to failure. While the battery has been scaled up to a $100 \mathrm{~W}$ bipolar unit, future work will focus on further improving the performance of the lead dioxide electrode and ensuring 100\% current efficiency for the dissolution of the lead dioxide at the positive electrode.

\section{Conclusions}

Lead dioxide coatings on titanium or carbon now offer a cheap alternative to precious metal anodes for a number of applications and provided they are used in controlled conditions, such coatings can have extended lifetimes with no significant contamination of the cell effluent by soluble lead species. Electrodes with lead dioxide coatings already have applications in the manufacture of chemicals as well as water and effluent treatment and such applications are likely to expand. 
Electrodeposition allows the fabrication of a family of lead dioxide layers with different physical and catalytic properties. The conditions for the deposition of pure $\alpha-\mathrm{PbO}_{2}$, pure $\beta-\mathrm{PbO}_{2}$ or mixtures of the phases are well established and it is possible to plate layers with very different surface morphologies and surface areas. In addition, the ability to deposit layers with very different dopants and doping levels, nanostructured layers and composites greatly expands the possibilities. It is possible to tailor both physical properties such as appearance, adhesion, stress and conductivity and chemical properties, particularly the rate of anode reactions. Particularly doping can have a large influence on electrode performance, introducing both greater stability and dramatically increasing catalytic activity. In some cases, oxidations that do not occur at undoped $\mathrm{PbO}_{2}$ will become mass transport controlled with appropriate doping.

As yet the literature is weak in closing the links between the deposition procedure and the structure/morphology of the lead dioxide layer as well as between this structure and electrode performance, particularly the catalytic activity and the stability of the lead dioxide surfaces. On the other hand, fundamental studies of lead dioxide coatings provide a new, and perhaps unique, avenue to understanding the relationship between the composition and structure of electrocatalysts and their activity. The diversity of $\mathrm{PbO}_{2}$ layers that can easily be electrodeposited is unparalleled with other materials. The requirement is for more careful characterisation of composition, structure, morphology and surface area and correlation with electrode performance.

\section{References}

1 D. Pletcher and F. C. Walsh, Industrial Electrochemistry, Chapman and Hall, London, 2nd edn, 1990.

2 G. Planté, Compt. Rend., 1859, 49, 402; G. Planté, Compt. Rend., $1860,50,640$.

3 G. W. Vinal, Storage Batteries, Willey, 1955.

4 C. K. Morehouse, R. Glicksman and G. S. Lozier, Proc. Inst. Radio Eng., 1958, 46, 1462.

5 J. P. Carr and N. A. Hampson, Chem. Rev., 1972, 72, 679-703.

6 H. Bode, Lead-Acid Battery, Willey-Interscience, 1977.

7 P. Ruetsehi, J. Power Sources, 1977/78, 2, 3-24.

8 The Electrochemistry of Lead, ed. A. T. Kuhn, Academic Press, New York, 1979.

9 R. M. Dell, Solid State Ionics, 2000, 134, 139-158.

10 A. J. Salkind, A. G. Cannone and F. A. Trumbure, in Handbook of Batteries, ed. D. Linden and T. B. Reddy, McGraw-Hill, 2002.

11 S. R. Ellis, N. A. Hampson, M. C. Ball and F. Wilkinson, J. Appl. Electrochem., 1986, 16, 159-167.

12 A. M. Couper, D. Pletcher and F. C. Walsh, Chem. Rev., 1990, 90, 837-865.

13 A. J. Bard, R. Parsons and J. Jordan, Standard Potentials in Aqueous Solutions, Marcel Dekker, 1985.

14 A. Hazza, D. Pletcher and R. G. A. Wills, Phys. Chem. Chem. Phys., 2004, 6, 1773-1778.

15 J. P. Carr, N. A. Hampson and R. Taylor, J. Electroanal. Chem., 1971, 33, 109-120.

16 W. Mindt, J. Electrochem. Soc., 1969, 116, 1076-1080.

17 International Centre for Diffraction Data Power Diffraction File, ICDD, Philadelphia, PA, card no., 72-2440 for $\alpha-\mathrm{PbO}_{2}$ and card no. 76-0564 for $\beta-\mathrm{PbO}_{2}, 2001$.

18 N. N. Fedorova, I. A. Aguf, L. M. Levinzon and M. A. Dasoyan, Ind. Lab. (USSR), 1964, 30, 914.

19 N. N. Fedorova, I. A. Aguf, L. M. Levinzon and M. A. Dasoyan, Sb. Rab. Khim. Isotochnikam Toka., 1966, 252.
20 J. Burbank, A. C. Simon and E. Willihnganz, Adv. Electrochem. Electrochem. Eng., 1971, 8, 157.

21 N. E. Bagshaw, R. L. Clarke and B. Halliwell, J. Appl. Chem., 1966, 16, 180.

22 A. I. Zaslavskii and S. S. Tolkachev, Zh. Fir. Khim., 1952, 26, 743.

23 V. H. Dodson, J. Electrochem. Soc., 1961, 108, 401-405.

24 N. Munichandraiah, J. Appl. Electrochem., 1992, 22, 825-829.

25 P. T. Moseley, J. L. Hutchison and M. A. M. Bourke, J. Electrochem. Soc., 1982, 129, 876-880.

26 J. P. Pohl and H. Rickert, in Electrodes of Conductive Metallic Oxides, ed. S. Trasatti, Elsevier Scientific Publishing Company, Amsterdam, 1980.

27 P. Rüetschi, J. Electrochem. Soc., 1992, 139, 1347-1351.

28 M. Heinemann, H. J. Terpstra, C. Haas and R. A. de Groot, Phys. Rev. B: Condens. Matter Mater. Phys., 1995, 52, 11740-11743.

29 D. J. Payne, R. G. Egdell, W. Hao, J. S. Foord, A. Walsh and G. W. Watson, Chem. Phys. Lett., 2005, 411, 181-185.

30 D. J. Payne, R. G. Egdell, D. S. L. Law, P. A. Glans, T. Learmonth, K. E. Smith, J. Guo, A. Walsh and G. W. Watson, J. Mater. Chem., 2007, 17, 267-277.

31 D. J. Payne, R. G. Egdell, G. Paolicelli, F. Offi, G. Panaccione, P. Lacovig, G. Monaco, G. Vanko, A. Walsh, G. W. Watson, J. Guo, G. Beamson, P. A. Glans, T. Learmonth and K. E. Smith, Phys. Rev. B: Condens. Matter Mater. Phys., 2007, 75, 153102.

32 M. Fleischmann and M. Liler, Trans. Faraday Soc., 1958, 54, $1370-1381$.

33 M. Fleischmann and H. R. Thirsk, Electrochim. Acta, 1959, 1, 146-160.

34 M. Fleischmann and H. R. Thirsk, Electrochim. Acta, 1960, 2, $22-49$.

35 M. Fleischmann, J. R. Mansfield, H. R. Thirsk, H. G. E. Wilson and L. Wynne-Jones, Electrochim. Acta, 1967, 12, 967-982.

36 Southampton Electrochemistry Group, Instrumental methods in electrochemistry, Ellis Horwood, New York, 1990.

37 M. Fleischmann, L. J. Li and L. M. Peter, Electrochim. Acta, 1989, 34, 475-483.

38 M. Y. Abyaneh, M. Fleischmann and E. Del Giudice, Electrochim. Acta, 2009, 54, 879-887.

39 N. A. Hampson, P. C. Jones and R. F. Phillips, Can. J. Chem., 1967, 45, 2039-2044.

40 N. A. Hampson, P. C. Jones and R. F. Phillips, Can. J. Chem., 1967, 45, 2045-2049.

41 N. A. Hampson, P. C. Jones and R. F. Phillips, Can. J. Chem., 1968, 46, 1325-1335.

42 M. Y. Abyaneh, V. Saez, J. González-García and T. J. Mason, Electrochim. Acta, 2010, 55, 3572-3579.

43 A. B. Velichenko, D. V. Girenko and F. I. Danilov, Electrochim. Acta, 1995, 40, 2803-2807.

44 A. B. Velichenko, D. V. Girenko and F. I. Danilov, J. Electroanal. Chem., 1996, 405, 127-132.

45 A. B. Velichenko, S. V. Kovalyov, A. N. Gnatenko, R. Amadelli, D. V. Girenko and F. I. Danilov, J. Electroanal. Chem., 1998, 454, 203-208.

46 A. B. Velichenko, R. Amadelli, A. Benedetti, D. V. Girenko, S. V. Kovalyov and F. I. Danilov, J. Electrochem. Soc., 2002, 149, C445-C449.

47 H. A. Laitinen and N. H. Watkins, J. Electrochem. Soc., 1976, 123, 804-809.

48 S. A. Campbell and L. M. Peter, J. Electroanal. Chem., 1991, 306, 185-194.

49 H. Chang and D. C. Johnson, J. Electrochem. Soc., 1989, 136, $17-22$.

50 H. Chang and D. C. Johnson, J. Electrochem. Soc., 1989, 136, 23-27.

51 M. Skyllas-Kazacos, J. Power Sources, 1984, 13, 55-64.

52 Z. Takehara and K. Kanamura, Electrochim. Acta, 1984, 29, $1643-1648$.

53 J. González-García, J. Iniesta, A. Aldaz and V. Montiel, New J. Chem., 1998, 22, 343-347.

54 J. González-García, J. Iniesta, E. Expósito, V. García-García, V. Montiel and A. Aldaz, Thin Solid Films, 1999, 352, 49-56.

55 J. González-García, F. Gallud, J. Iniesta, V. Montiel, A. Aldaz and A. Lasia, J. Electrochem. Soc., 2000, 147, 2969-2974. 
56 J. González-García, F. Gallud, J. Iniesta, V. Montiel, A. Aldaz and A. Lasia, Electroanalysis, 2001, 13, 1258-1264.

57 J. González-García, F. Gallud, J. Iniesta, V. Montiel, A. Aldaz and A. Lasia, New J. Chem., 2001, 25, 1195-1198.

58 J. González-García, V. Sáez, J. Iniesta, V. Montiel and A. Aldaz, Electrochem. Commun., 2002, 4, 370-373.

59 J. González-García, F. Gallud, J. Iniesta, V. Montiel, A. Aldaz and A. Lasia, Electrochem. Commun., 2004, 6, 757-761.

60 A. J. Saterlay, S. J. Wilkins, K. B. Holt, J. S. Foord, R. G. Compton and F. Marken, J. Electrochem. Soc., 2001, 148, E66-E72.

61 F. Marken, Y. C. Tsai, A. J. Saterlay, B. A. Coles, D. Tibbetts, K. Holt, C. H. Goeting, J. S. Foord and R. G. Compton, J. Solid State Electrochem., 2001, 5, 313-318.

62 K. C. Narasimham and H. V. K. Udupa, J. Electrochem. Soc., 1976, 123, 1294-1298.

63 R. Thangappan, S. Nachippan and S. Sampath, Ind. Eng. Chem. Prod. Res. Dev., 1970, 9, 563-567.

64 K. C. Narasimham, S. Sundararajan and H. V. K. Udupa, J. Electrochem. Soc., 1961, 108, 798-805.

65 K. C. Narasimham, P. S. Gomathi and H. V. K. Udupa, J. Appl. Electrochem., 1976, 6, 397-401.

66 N. Thiagarajan, K. C. Narasimham and H. V. K. Udupa, Chem. Ing. Tech., 1971, 43, 216.

67 H. V. K. Udupa, S. Sampath, K. C. Narasimham, M. Nagalingam, N. Thiagarajan, G. Subramanian, P. Subbiah, R. Palanisamy, S. J. Peter, S. Pushpavanam and M. Sadagopalan, J. Appl. Chem. Biotechnol., 1974, 24, 43-47.

68 N. Munichandraiah and S. Sathyanarayana, J. Appl. Electrochem., 1990, 20, 1059-1062.

69 N. Munichandraiah and S. Sathyanarayana, J. Appl. Electrochem., 1988, 18, 314-316.

70 N. Munichandraiah and S. Sathyanarayana, J. Appl. Electrochem., 1987, 17, 33-48.

71 N. B. Tahar and A. Savall, J. Electrochem. Soc., 1998, 145, $3427-3434$.

72 A. H. Ras and J. F. van Staden, J. Appl. Electrochem., 1999, 29, 313-319.

73 J. C. Grigger, in The Encyclopedia of Electrochemistry, ed. C. A. Hampel, Reinhold, New York, 1964.

74 D. Devilliers, M. T. D. Thi, E. Mahe, V. Dauriac and N. Lequeux, J. Electroanal. Chem., 2004, 573, 227-239.

75 D. W. Wabner, R. Huss, F. Hindelang, H. P. Fritz and D. Missol, Z. Naturforsch., 1976, 31B, 45-50.

76 D. W. Wabner, H. P. Fritz and R. Huss, Chem. Ing. Tech., 1977, 49, 329-331.

77 Ch. Comninellis and E. Plattner, J. Appl. Electrochem., 1982, 12, 399-404.

78 D. Devilliers, M. T. D. Thi, E. Mahe and Q. Le Xuan, Electrochim. Acta, 2003, 48, 4301-4309.

79 M. Ueda, A. Watanabe, T. Kameyama, Y. Matsumoto, M. Sekimoto and T. Shimamune, J. Appl. Electrochem., 1995, 25, 817-822.

80 F. Hine, M. Yasuda, T. Iida, Y. Ogata and K. Hara, Electrochim. Acta, 1984, 29, 1447-1452.

81 J. Feng and D. C. Johnson, J. Electrochem. Soc., 1991, 138, 3328.

82 Y. Mohd and D. Pletcher, Electrochim. Acta, 2006, 52, 786-793.

83 K. S. A. Gnanasekaran, K. C. Narasimham and H. V. K. Udupa, Electrochim. Acta, 1970, 15, 1615-1622.

84 J. C. G. Thanos and D. W. Wabner, J. Electroanal. Chem., 1985, 182, 25-36.

85 P. Shen and X. Wei, Electrochim. Acta, 2003, 48, 1743-1747.

86 Y. Liu and H. Liu, Electrochim. Acta, 2008, 53, 5077-5083.

87 A. B. Velichenko, R. Amadelli, E. V. Gruzdeva, T. V. Luk'yanenko and F. I. Danilov, J. Power Sources, 2009, 191, 103-110.

88 J. Cao, H. Zhao, F. Cao, J. Zhang and C. Cao, Electrochim. Acta, 2009, 54, 2595-2602.

89 X. Li, D. Pletcher and F. C. Walsh, Electrochim. Acta, 2009, 54, 4688-4695.

90 C. T. J. Low, D. Pletcher and F. C. Walsh, Electrochem. Commun., 2009, 11, 1301-1304.

91 I. Sires, C. T. J. Low, C. Ponce de Leon and F. C. Walsh, Electrochim. Acta, 2010, 55, 2163-2172.

92 A. B. Velichenko, R. Amadelli, V. A. Knysh, T. V. Luk'yanenko and F. I. Danilov, J. Electroanal. Chem., 2009, 632, 192-196.
93 D. Wabner, Habil. Thesis, Technical University Munich, 1976.

94 M. E. Hyde, R. M. J. Jacobs and R. G. Compton, J. Phys. Chem. B, 2004, 108, 6381-6390.

95 N. Munichandraiah and S. Sathyanarayana, J. Appl. Electrochem., 1987, 17, 22-32.

96 M. Ghaemi, E. Ghafouri and J. Neshati, J. Power Sources, 2006, $157,550-562$.

97 T. C. Wen, M. G. Wei and K. L. Lin, J. Electrochem. Soc., 1990, 137, 2700-2702.

98 S. Ghasemi, M. F. Mousavi and M. Shamsipur, Electrochim. Acta, 2007, 53, 459- 467.

99 K. S. A. Gnanasekaran, K. C. Narasimham and H. V. K. Udupa, J. Appl. Electrochem., 1976, 6, 189-198.

100 D. Pletcher and R. G. A. Wills, Phys. Chem. Chem. Phys., 2004, 6, 1779-1785.

101 D. Pletcher and R. G. A. Wills, J. Power Sources, 2005, 149, 96-102.

102 A. Hazza, D. Pletcher and R. G. A. Wills, J. Power Sources, 2005, 149, 103-111.

103 D. Pletcher, H. Zhou, G. Kear, C. T. J. Low, F. C. Walsh and R. G. A. Wills, J. Power Sources, 2008, 180, 621-629.

104 D. Pletcher, H. Zhou, G. Kear, C. T. J. Low, F. C. Walsh and R. G. A. Wills, J. Power Sources, 2008, 180, 630-634.

105 J. Collins, G. Kear, X. Li, C. T. J. Low, D. Pletcher, R. C. Tangirala, D. Stratton-Campbell, F. C. Walsh and C. Zhang, J. Power Sources, 2010, 195, 1731-1738.

106 J. Collins, X. Li, D. Pletcher, R. C. Tangirala, D. StrattonCampbell, F. C. Walsh and C. Zhang, J. Power Sources, 2010, 195, 2975-2978.

107 R. G. A. Wills, J. Collins, D. Stratton-Campbell, C. T. J. Low, D. Pletcher and F. C. Walsh, J. Appl. Electrochem., 2010, 40, 955-965.

108 A. Delmastro and M. Maja, J. Electrochem. Soc., 1984, 131, 2756.

109 I. H. Yeo, S. Kim, R. Jacobson and D. C. Johnson, J. Electrochem. Soc., 1989, 136, 1395-1401.

110 R. Amadelli, L. Armelao, E. Tondello, S. Daolio, F. Fabrizio, C. Pagura and A. Velichenko, Appl. Surf. Sci., 1999, 142, 200-203.

111 D. C. Johnson, H. Chang, J. Feng and W. Wang, in Electrochemistry for Cleaner Environment, ed. J. D. Genders and N. L. Weinberg, The Electrosynthesis Company Inc., New York, 1992.

112 K. L. Pamplin and D. C. Johnson, J. Electrochem. Soc., 1996, 143, 2119-2125.

113 K. Mondal, N. V. Mandich and S. B. Lalvani, J. Appl. Electrochem., 2001, 31, 165-173.

114 W. R. LaCourse, Y. L. Hsiao and D. C. Johnson, J. Electrochem. Soc., 1989, 136, 3714-3719.

115 K. T. Kawagoe and D. C. Johnson, J. Electrochem. Soc., 1994, 141, 3404-3409.

116 J. Feng, L. L. Houk, D. C. Johnson, S. N. Lowery and J. J. Carey, J. Electrochem. Soc., 1995, 142, 3626-3632.

117 L. S. Andrade, L. A. M. Ruotolo, R. C. Rocha-Filho, N. Bocchi, S. R. Biaggio, J. Iniesta, V. García-Garcia and V. Montiel, Chemosphere, 2007, 66, 2035-2043.

118 L. S. Andrade, R. C. Rocha-Filho, N. Bocchi, S. R. Biaggio, J. Iniesta, V. García-Garcia and V. Montiel, J. Hazard. Mater., 2008, 153, 252-260.

119 I. H. Yeo and D. C. Johnson, J. Electrochem. Soc., 1987, 134, 1973-1977.

120 H. Chang and D. C. Johnson, J. Electrochem. Soc., 1990, 137, 2452-2457.

121 J. Iniesta, J. González-Garca, E. Expósito, V. Montiel and A. Aldaz, Water Res., 2001, 35, 3291-3300.

122 J. Iniesta, E. Expósito, J. González-Garca, V. Montiel and A. Aldaz, J. Electrochem. Soc., 2002, 149, D57-D62.

123 H. Liu, Y. Liu, C. Zhang and R. Shen, J. Appl. Electrochem., 2008, 38, 101-108.

124 J. Feng and D. C. Johnson, J. Electrochem. Soc., 1994, 141, 2708-2711.

125 J. Cao, H. Zhao, F. Cao and J. Zhang, Electrochim. Acta, 2007, 52, 7870-7876.

126 R. Amadelli, L. Armelao, A. B. Velichenko, N. V. Nikolenko, D. V. Girenko, S. V. Kovslyov and F. I. Dsnilov, Electrochim. Acta, 1999, 45, 713-720. 
127 J. Ge and D. C. Johnson, J. Electrochem. Soc., 1995, 142, $1525-1531$.

128 G. Cao, Nanostructures \& nanomaterials: synthesis properties \& applications, Imperial College Press, London, 2004.

129 G. A. Ozin, Nanochemistry: a chemical approach to nanomaterials, Royal Society of Chemistry, Cambridge, 2005.

130 R. Inguanta, S. Piazza and C. Sunseri, J. Electrochem. Soc., 2008, 155, K205-K210.

131 P. Perret, T. Brousse, D. Bélanger and D. Guay, J. Electrochem. Soc., 2009, 156, A645-A651.

132 P. N. Bartlett, T. Dunford and M. A. Ghanem, J. Mater. Chem., 2002, 12, 3130-3135.

133 P. J. Blood, I. J. Brown and S. Sotiropoulos, J. Appl. Electrochem., 2004, 34, 1-7.

134 S. Ghasemi, H. Karami, M. F. Mousavi and M. Shamsipur, Electrochem. Commun., 2005, 7, 1257-1264.

135 S. Ghasemi, M. F. Mousavi, H. Karami, M. Shamsipur and S. H. Kazemi, Electrochim. Acta, 2006, 52, 1596-1602.

136 J. P. Celis, J. R. Roos, C. Buelens and J. Fransaer, Trans. Inst. Met. Finish., 1991, 69, 133-139.

137 A. Hovestad and L. J. J. Janssen, J. Appl. Electrochem., 1995, 25, $519-527$.

138 C. T. J. Low, R. G. A. Wills and F. C. Walsh, Surf. Coat. Technol., 2006, 201, 371-383.

139 A. Yoshiyama, T. Nonaka, M. Sekimoto and Y. Nishiki, Chem. Lett., 1994, 1565-1568.

140 C. N. Ho and B. J. Hwang, J. Electroanal. Chem., 1994, 377, $177-190$.

141 S. Tong, C. Ma and H. Feng, Electrochim. Acta, 2008, 53, 3002-3006.

142 B. J. Hwang and K. L. Lee, J. Appl. Electrochem., 1996, 26, 153-159.

143 M. Musiani, Chem. Commun., 1996, 2403-2404.

144 M. Musiani, F. Furlanetto and P. Guerriero, J. Electroanal. Chem., 1997, 440, 131-138.

145 M. Musiani, F. Furlanetto and P. Guerriero, J. Electrochem. Soc., 1998, 145, 555-560.

146 M. Musiani and P. Guerriero, Electrochim. Acta, 1998, 44, 1499-1507.

147 R. Bertoncello, F. Furlanetto, P. Guerriero and M. Musiani, Electrochim. Acta, 1999, 44, 4061-4068.

148 S. Cattarin, I. Frateur, P. Guerriero and M. Musiani, Electrochim. Acta, 2000, 45, 2279-2288.

149 U. Casellato, S. Cattarin, P. Guerriero and M. Musiani, Chem. Mater., 1997, 9, 960-966.

150 M. Musiani, F. Furlanetto and R. Bertoncello, J. Electroanal. Chem., 1999, 465, 160-167.

151 R. Bertoncello, S. Cattarin, I. Frateur and M. Musiani, J. Electroanal. Chem., 2000, 492, 145-149.

152 M. Musiani, Electrochim. Acta, 2000, 45, 3397-3402.

153 U. Casellato, S. Cattarin and M. Musiani, Electrochim. Acta, 2003, 48, 3991-3998.

154 S. Cattarin and M. Musiani, Electrochim. Acta, 2007, 52, 2796-2805.

155 G. Li, J. Qu, X. Zhang and J. Ge, Water Res., 2006, 40, 213-220.

156 G. Li, J. Qu, X. Zhang, Hu. Liu and H. Liu, J. Mol. Catal. A. Chem., 2006, 259, 238-244.

157 J. Li, L. Zheng, L. Li, G. Shi, Y. Xian and L. Jin, Electroanalysis, 2006, 18, 2251-2256.

158 R. Amadelli, L. Samiolo, A. B. Velichenko, V. A. Knysh, T. V. Luk'yanenko and F. I. Danilov, Electrochim. Acta, 2009, 54, 5239-5245.

159 A. B. Velichenko, V. A. Knysh, T. V. Luk'yanenko, D. Devilliers and F. I. Danilov, Russ. J. Electrochem., 2008, 44, 1251-1256.

160 Y. Song, G. Wei and R. Xiong, Electrochim. Acta, 2007, 52, $7022-7027$.

161 R. A. Baker, J. Electrochem. Soc., 1962, 109, 337-338.

162 A. T. Kuhn and P. M. Wright, in Industrial Electrochemical Processes, ed. A. T. Kuhn, Elsevier, 1971.

163 J. C. Grigger, H. C. Miller and F. D. Loomis, J. Electrochem. Soc., 1958, 105, 100-102.

164 J. C. Schumacher, D. R. Stern and P. R. Graham, J. Electrochem. Soc., 1958, 105, 151-155.

165 T. Osuga and K. Sugino, J. Electrochem. Soc., 1957, 104, $448-451$.
166 A. T. Kuhn and R. L. Clarke, J. Appl. Chem. Biotechnol., 1976, 26, 407-418.

167 D. Pletcher and S. J. D. Tait, J. Appl. Electrochem., 1981, 11, 493-502.

168 R. L Clarke, in Electrosynthesis-From Laboratory to Pilot to Production, eds. J. D. Genders and D. Pletcher, The Electrosynthesis Co, 1990, 93.

169 T. H. Randle and A. T. Kuhn, Aust. J. Chem., 1989, 42, 229-242.

170 T. H. Randle and A. T. Kuhn, Aust. J. Chem., 1989, 42, $1527-1545$.

171 I. M. Dalrymple and J. P. Millington, J. Appl. Electrochem., 1986, 16, 885-893.

172 R. M. Spotnitz, P. R. Kreh, J. T. Lundquist and P. J. Press, J. Appl. Electrochem., 1990, 20, 209-215.

173 H. F. Conway, E. B. Lancaster and V. E. Sohns, Electrochem. Technol., 1964, 2, 43.

174 B. Langlais, D. A. Reckhow and D. R. Brink, Ozone in Water Treatment Application and Engineering, Lewis Publishers, Boca Raton, 1991

175 K. Kinoshita, Electrochemical Oxygen Technology, John Wiley \& Sons, NewYork, 1992.

176 W. W. Stender, Trans. Am. Electrochem. Soc., 1935, 68, 510.

177 D. P. Semchenko, E. T. Lyubushkina and V. I. Lyubushkin, Elektrokhimiya, 1973, 9, 1744.

178 D. P. Semchenko, E. T. Lyubushkina and V. I. Lyubushkin, Otkryitiya Izobret. Prom. Obraztsy Tovarnye Znaki, 1974, 51, 225.

179 D. P. Semchenko, E. T. Lyubushkina and V. I. Lyuhushkin, Izv. Sev.-Kauk. Nauchn. Tsentra Vyssh. Shk. Ser. Tekn. Nauk, 1975, 3, 98.

180 H. P. Fritz, J. Thanos and D. W. Wabner, Z. Naturforsch., B: Anorg. Chem., Org. Chem., 1979, 34, 1617-1627.

181 P. C. Foller and C. W. Tobias, J. Phys. Chem., 1981, 85, $3238-3244$

182 P. C. Foller and C. W. Tobias, J. Electrochem. Soc., 1982, 129, 506-515.

183 P. C. Foller and C. W. Tobias, J. Electrochem. Soc., 1982, 129, $567-570$

184 P. C. Foller and M. L. Goodwin, Ozone: Sci. Eng., 1984, 6, 29-36.

185 P. C. Foller and G. H. Kelsall, J. Appl. Electrochem., 1993, 23, 996-1010.

186 J. C. G. Thanos, H. P. Fritz and D. W. Wabner, J. Appl. Electrochem., 1984, 14, 389-399.

187 D. W. Wabner and C. Grambow, J. Electroanal. Chem., 1985, 195, 95-108.

188 S. Stucki, G. Theis, R. Kötz, H. Devantay and H. J. Christen, J. Electrochem. Soc., 1985, 132, 367-371.

189 H. Baumann and S. Stucki, Swiss Chem, 1986, 8, 31.

190 L. Vogel and H. P. Klein, Brown Boveri Rev., 1986, 8, 451-456.

191 S. Stucki, H. Baumann, R. Kötz and H. J. Christen, J. Appl. Electrochem., 1987, 17, 773-778.

192 R. Kötz and S. Stucki, J. Electroanal. Chem., 1987, 228, 407-415.

193 J. E. Graves, D. Pletcher, R. L. Clarke and F. C. Walsh, J. Appl. Electrochem., 1992, 22, 200-203.

194 A. A. Babak, R. Amadelli, A. De Battisti and V. N. Fateev, Electrochim. Acta, 1994, 39, 1597-1602.

195 R. Amadelli, T. Bonato, A. De Battisti, A. Babak and A. B. Velichenko, in Proceedings of the Symposium on Energy and Electrochemical Processing for a Cleaner Environment, ed. C. W. Walton and E. J. Rudd, The Electrochemical Society Inc. Pennington NJ, 1998, pp. 51-60.

196 L. M. Da Silva, L. A. De Faria and J. F. C. Boodts, Pure Appl. Chem., 2001, 73, 1871-1884.

197 L. M. Da Silva, L. A. De Faria and J. F. C. Boodts, Electrochim. Acta, 2001, 47, 395-403.

198 L. M. Da Silva, M. H. P. Santana and J. F. C. Boodts, Quim. Nova, 2003, 26, 880-888.

199 L. M. Da Silva, L. A. de Faria and J. F. C. Boodts, Electrochim. Acta, 2003, 48, 699-709.

200 L. M. Da Silva, D. V. Franco, J. C. Forti, W. F. Jardim and J. F. C. Boodts, J. Appl. Electrochem., 2006, 36, 523-530.

201 K. Onda, T. Ohba, H. Kusunoki, S. Takezawa, D. Sunakawa and T. Araki, J. Electrochem. Soc., 2005, 152, D177-D183.

202 R. Amadelli, A. De Battisti, D. V. Girenko, S. V. Kovslyov and A. B. Velichenko, Electrochim. Acta, 2000, 46, 341-347. 
203 C. A. Martínez-Huitle and S. Ferro, Chem. Soc. Rev., 2006, 35, 1324-1340.

204 M. Panizza and G. Cerisola, Chem. Rev., 2009, 109, $6541-6569$

205 K. Rajeshwar, J. G. Ibanez and G. M. Swain, J. Appl. Electrochem., 1994, 24, 1077-1091.

206 Electrochemistry for the Environment, ed. Ch. Comninellis and G. Chen, Springer, 2010.

207 J. E. Vitt and D. C. Johnson, J. Electrochem. Soc., 1992, 139, 774-778.

208 Ch. Comninellis, Electrochim. Acta, 1994, 39, 1857-1862.

209 Y. Cong and Z. Wu, J. Phys. Chem. C, 2007, 111, 3442-3446.

210 D. Wu, M. Liu, D. Dong and X. Zhou, Microchem. J., 2007, 85, 250-256.

211 D. Wabner and C. Grambow, J. Electroanal. Chem., 1985, 195, 95-108.

212 C. A. Martínez-Huitle, M. A. Quiroz, Ch. Comninellis, S. Ferro and A. De Battisti, Electrochim. Acta, 2004, 50, 949-956.

213 D. Pavlov and B. Monahov, J. Electrochem. Soc., 1996, 143, 3616-3629.

214 D. Pavlov, J. Electrochem. Soc., 1992, 139, 3075-3080.

215 J. M Aquino, R. C. Rocha-Filho, N. Bocchi and S. R. Biaggio, J. Appl. Electrochem., 2010, 40, 1751-1757.

216 K. Kawagoe and D. C. Johnson, J. Electrochem. Soc., 1994, 141, 3404-3409.

217 N. B. Tahar and A. Savall, J. Appl. Electrochem., 1999, 29, 277-283.

218 C. Bockz and B. MacDougall, J. Electrochem. Soc., 1999, 146, 2925-2932.

219 A. M. Polcaro, S. Palmas, F. Renoldi and M. Mascia, J. Appl. Electrochem., 1999, 29, 147-151.

220 J. D. Rodgers, W. Jedral and N. J. Bunce, Environ. Sci. Technol., 1999, 33, 1453-1457.

221 V. L. Gherardini, P. A. Michaud, M. Panizza, Ch. Comninellis and N. Vatistasa, J. Electrochem. Soc., 2001, 148, D78-D82.

222 M. Zhou, Q. Dai, L. Lei, C. Ma and D. Wang, Environ. Sci. Technol., 2005, 39, 363-370.

223 S. Abaci, U. Tamer, K. Pekmez and A. Yildiz, Appl. Surf. Sci., 2005, 240, 112-119.

224 N. B. Tahar and A. Savall, J. New Mater. Electrochem. Syst., 1999, 2, 19-22.

225 V. Smith de Sucre and A. P. Watkinson, Can. J. Chem. Eng., 1981, 59, 52-59.

226 H. Sharifian and D. W. Kirk, J. Electrochem. Soc., 1986, 133, 921-924.

227 Ch. Comninellis, Trans. IChemE B, 1992, 70, 219-224.

228 U. Schumann and P. Grundler, Water Res., 1998, 32, 2835-2842.

229 J. Grimm, D. Bessarabov, W. Maier, S. Storck and R. D. Sanderson, Desalination, 1998, 115, 295-302.

230 E. Weiss, K. Groenen-Serrano and A. Savall, J. Appl. Electrochem., 2008, 38, 329-337.
231 N. B. Tahar, R. Abdelhédi and A. Savall, J. Appl. Electrochem., 2009, 39, 663-669.

232 N. B. Tahar and A. Savall, Electrochim. Acta, 2009, 54, 4809-4816.

233 D. W. Kirk, H. Sharifian and F. R. Foulkes, J. Appl. Electrochem., 1985, 15, 285-292.

234 M. A. Quiroz, S. Reyna, C. A. Martínez-Huitle, S. Ferro and A. De Battisti, Appl. Catal., B, 2005, 59, 259-266.

235 H. Liu, Y. Liu, C. Zhang and R. Shen, J. Appl. Electrochem., 2008, 38, 101-108.

236 M. Panizza and G. Cerisola, Electrochim. Acta, 2004, 49, 3221-3226.

237 F. Bonfatti, S. Ferro, F. Lavezzo, M. Malacarne, G. Lodi and A. De Battisti, J. Electrochem. Soc., 1999, 146, 2175-2179.

238 F. Bonfatti, S. Ferro, F. Lavezzo, M. Malacarne, G. Lodi and A. De Battisti, J. Electrochem. Soc., 2000, 147, 592-596.

239 C. A. Martínez-Huitle, S. Ferro and A. De Battisti, Electrochim. Acta, 2004, 49, 4027-4034.

240 C. A. Martínez-Huitle, S. Ferro and A. De Battisti, J. Appl. Electrochem., 2005, 35, 1087-1093.

241 C. A. Martínez-Huitle, M. A. Quiroz, Ch. Comninellis, S. Ferro and A. De Battisti, Electrochim. Acta, 2004, 50, 949-956.

242 P. G. Keech and N. J. Bunce, J. Appl. Electrochem., 2003, 33, $79-83$.

243 M. Panizza and G. Cerisola, Environ. Sci. Technol., 2004, 38, $5470-5475$.

244 O. Scialdone, A. Galia and G. Filardo, Electrochim. Acta, 2008, 53, 7220-7225.

245 C. Flox, C. Arias, E. Brillas, A. Savall and K. Groenen-Serrano, Chemosphere, 2009, 74, 1340-1347.

246 I. Sirés, E. Brillas, G. Cerisola and M. Panizza, J. Electroanal. Chem., 2008, 613, 151-159.

247 M. Panizza, I. Sirés and G. Cerisola, J. Appl. Electrochem., 2008, 38, $923-929$

248 C. A. Martínez-Huitle, A. De Battisti, S. Ferro, S. Reyna, M. Cerro-lopez and M. A. Quiro, Environ. Sci. Technol., 2008, 42, 6929-6935.

249 E. Weiss, K. Groenen-Serrano and A. Savall, J. New Mater. Electrochem. Syst., 2006, 9, 249-256.

250 M. Panizza and G. Cerisola, Appl. Catal., B, 2007, 75, 95-101.

251 I. Sirés, C. T. J. Low, C. Ponce-de-León and F. C. Walsh, Electrochem. Commun., 2010, 12, 70-74.

252 L. Kaba, G. D. Hitchens and J. O’M. Bockris, J. Electrochem. Soc., 1990, 137, 1341-1345.

253 L. C. Chiang, J. E. Chang and T. C. Wen, Water Res., 1995, 29, 671-678.

254 R. Cossu, A. M. Polcaro, M. C. Lavagnolo, M. Mascia, S. Palmas and F. Renoldi, Environ. Sci. Technol., 1998, 32, 3570-3573.

255 M. Panizza, M. Delucchi and I. Sirés, J. Appl. Electrochem., 2010, 40, 1721-1727.

256 D. Pletcher, ECS Trans., 2010, 28, 1-10. 